\title{
Inducing death in tumor cells: roles of the inhibitor of
}

\section{apoptosis proteins [version 1; peer review: 3 approved]}

\section{Darren Finlay ${ }^{*}$, Peter Teriete*, Mitchell Vamos*, Nicholas D. P. Cosford, Kristiina Vuori}

NCI-Designated Cancer Center, Sanford Burnham Prebys Medical Discovery Institute, 10901 North Torrey Pines Road, La Jolla, CA, 92037, USA

* Equal contributors

V1 First published: 27 Apr 2017, 6(F1000 Faculty Rev):587
https://doi.org/10.12688/f1000research.10625.1

Latest published: 27 Apr 2017, 6(F1000 Faculty Rev):587

https://doi.org/10.12688/f1000research.10625.1

\section{Abstract}

The heterogeneous group of diseases collectively termed cancer results not just from aberrant cellular proliferation but also from a lack of accompanying homeostatic cell death. Indeed, cancer cells regularly acquire resistance to programmed cell death, or apoptosis, which not only supports cancer progression but also leads to resistance to therapeutic agents. Thus, various approaches have been undertaken in order to induce apoptosis in tumor cells for therapeutic purposes. Here, we will focus our discussion on agents that directly affect the apoptotic machinery itself rather than on drugs that induce apoptosis in tumor cells indirectly, such as by DNA damage or kinase dependency inhibition. As the roles of the Bcl-2 family have been extensively studied and reviewed recently, we will focus in this review specifically on the inhibitor of apoptosis protein (IAP) family. IAPs are a disparate group of proteins that all contain a baculovirus IAP repeat domain, which is important for the inhibition of apoptosis in some, but not all, family members. We describe each of the family members with respect to their structural and functional similarities and differences and their respective roles in cancer. Finally, we also review the current state of IAPs as targets for anti-cancer therapeutics and discuss the current clinical state of IAP antagonists.

Keywords

apoptosis, tumours, cancer, IAPs, inhibitor of apoptosis proteins
Open Peer Review

$\begin{array}{ccc}\text { Approval Status } & \checkmark & \\ 1 & 2 & 3\end{array}$

version 1

27 Apr 2017

Faculty Reviews are review articles written by the prestigious Members of Faculty Opinions. The articles are commissioned and peer reviewed before publication to ensure that the final, published version is comprehensive and accessible. The reviewers who approved the final version are listed with their names and affiliations.

1. Craig M Walsh, University of California, Irvine, Irvine, USA

2. Domagoj Vucic, Department of Early Discovery Biochemistry, Genentech, South San Francisco, South San Francisco, USA

3. Robert G Korneluk, Apoptosis Research

Centre, Children's Hospital of Eastern Ontario Research Institute, Ottawa, Canada

Eric C LaCasse, Apoptosis Research Centre, Children's Hospital of Eastern Ontario Research Institute, Ottawa, Canada 
Shawn T Beug, Apoptosis Research Centre, Children's Hospital of Eastern Ontario

Research Institute, Ottawa, Canada

Any comments on the article can be found at the end of the article.

Corresponding authors: Darren Finlay (dfinlay@sbpdiscovery.org), Kristiina Vuori (kvuori@sbpdiscovery.org)

Competing interests: No competing interests were disclosed.

Grant information: This work was supported by National Institutes of Health grant R01CA195227 to DF and NDPC.

The funders had no role in study design, data collection and analysis, decision to publish, or preparation of the manuscript.

Copyright: ( 2017 Finlay D et al. This is an open access article distributed under the terms of the Creative Commons Attribution License, which permits unrestricted use, distribution, and reproduction in any medium, provided the original work is properly cited. Data associated with the article are available under the terms of the Creative Commons Zero "No rights reserved" data waiver (CC0 1.0 Public domain dedication).

How to cite this article: Finlay $D$, Teriete $P$, Vamos $M$ et al. Inducing death in tumor cells: roles of the inhibitor of apoptosis proteins [version 1; peer review: 3 approved] F1000Research 2017, 6(F1000 Faculty Rev):587 https://doi.org/10.12688/f1000research.10625.1

First published: 27 Apr 2017, 6(F1000 Faculty Rev):587 https://doi.org/10.12688/f1000research.10625.1 


\section{Introduction to inhibitor of apoptosis family of proteins}

The inhibitor of apoptosis protein (IAP) family is a functionally and structurally related group of proteins that serve as endogenous inhibitors of programmed cell death, or apoptosis. In addition, some family members are regulators of another form of programmed cell death termed necroptosis ${ }^{1,2}$. Whilst some of the IAPs have also been shown to be involved in immune regulation ${ }^{3,4}$, chromosome segregation, and cytokinesis ${ }^{5-7}$, this review will focus on their roles in explicitly regulating apoptosis. Although the various IAPs have somewhat differing functions, they are linked by one unique domain: membership of the IAP family is ascribed if the gene/protein in question possesses a baculovirus IAP repeat (BIR) domain. Indeed, as the name suggests, BIR domains were first identified in a baculoviral protein capable of inhibiting cell death in virally infected cells ${ }^{8-10}$. BIR domains are zinc finger domains and invariantly contain three cysteines and one histidine, which co-ordinate the zinc ion ${ }^{10}$, and these domains are involved in various protein-protein interactions (PPIs). IAPs were subsequently identified and characterized by various techniques in yeast, worms, insects, and mammalian cells ${ }^{5,11-15}$. The first human IAP revealed was neuronal apoptosis inhibitory protein (NAIP or BIRC1), which was serendipitously discovered in a search for genes involved in the autosomal recessive condition spinal muscular atrophy (SMA) ${ }^{16}$. The next human IAPs to be characterized were the cellular IAPs 1 and 2: cIAP1 (or BIRC2) and cIAP2 (or BIRC3). These proteins were discovered to have a role in tumor necrosis factor receptor (TNFR) signaling through association with the adaptor proteins TRAF1 and TRAF2 ${ }^{17-20}$. The fact that several proteins shared the common BIR domain led to the identification of more family members via traditional homologymatching database searches (reviewed in 21). Notably, many of these proteins were further shown to be involved in the regulation of apoptosis ${ }^{15,22-27}$. Rounding out the group of eight human BIRcontaining proteins are XIAP (BIRC4), Survivin (BIRC5), Apollon (BIRC6), Melanoma IAP (ML-IAP or BIRC7), and IAP-like protein 2 (ILP-2 or BIRC8) 15,22,25,28-37. A schematic of the general IAP family structure is shown in Figure 1. Figure 2 shows the intracellular signaling interplay of IAPs with respect to cell survival and apoptosis.

Survivin and ML-IAP are small proteins with only one BIR domain, yet their functions are enigmatic, having been ascribed to various processes, including apoptosis inhibition. As such, their roles, especially with respect to cancer, will be discussed in greater detail later in this review. ML-IAP additionally possesses an E3 ubiquitin ligase domain named RING (really interesting new gene), a domain also present in other IAPs and believed to be important in many signaling events ${ }^{38-41}$. ILP-2, likewise with only one BIR domain, also contains a RING domain and a ubiquitinassociated (UBA) domain. Whilst ILP-2 shows high homology to XIAP, it is a product of a separate gene and its expression in healthy tissues appears to be restricted to the testes ${ }^{36}$. Overexpression studies have shown that ILP-2 has no effect on extrinsic death receptor-induced apoptosis but that it can inhibit intrinsic (also known as mitochondrial) apoptosis through a potential interaction with caspase-9, an apical protease involved in mitochondrial apoptosis $^{36}$. However, others have shown that its BIR domain is unstable and, as such, it is only a weak binder of caspase-9, at least in the absence of other cellular factors ${ }^{42}$.

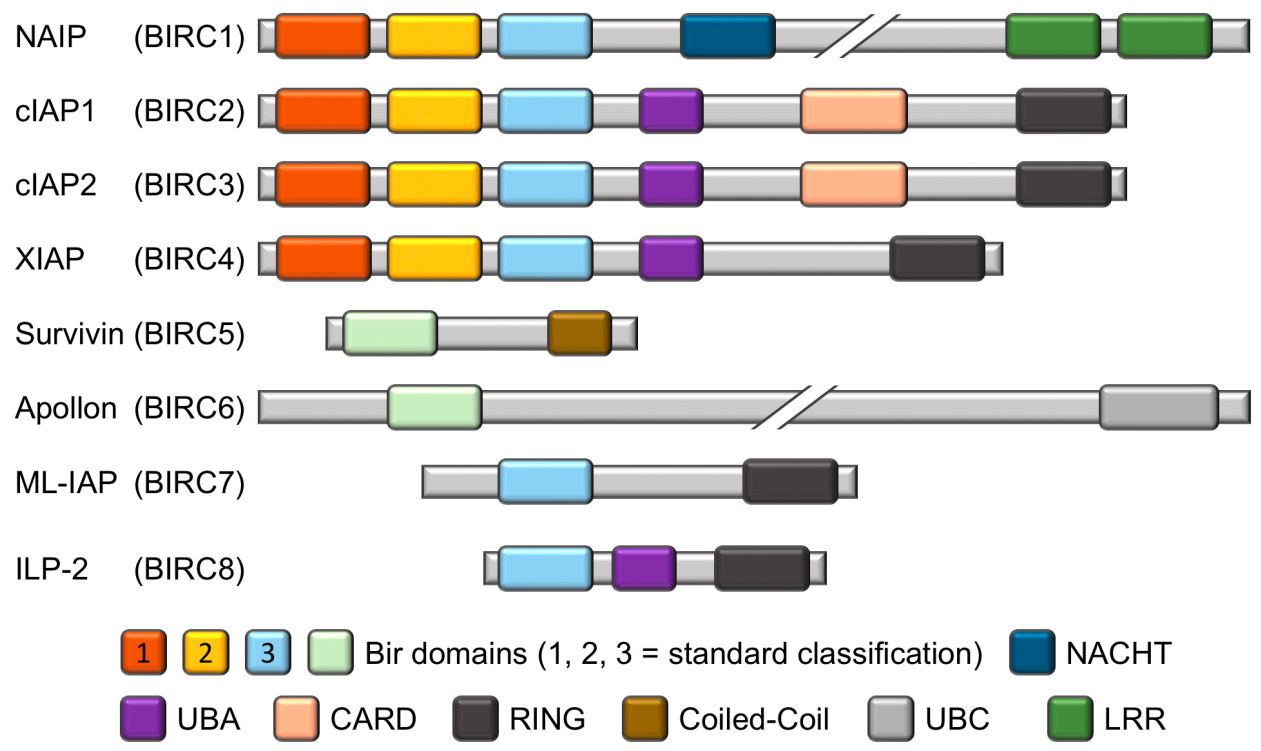

Figure 1. Domain structures of all known members of the human inhibitor of apoptosis protein (IAP) family, with a focus on the different baculovirus IAP repeat (BIR) domains. The representation of the homology between the different BIR domains of the IAP family reflects the accepted designation of BIR1, BIR2, and BIR3. The BIR domains of Survivin (BIRC5) and Apollon (BIRC6) can be aligned with either BIR1 or BIR2, depending on the specific alignment criteria, but owing to their uniqueness they are colored and labeled accordingly. CARD, caspase recruitment domain; cIAP1, cellular inhibitor of apoptosis protein 1; cIAP2, cellular inhibitor of apoptosis protein 2; ILP-2, inhibitor of apoptosis protein-like protein 2; LRR, leucine-rich repeat; ML-IAP, melanoma inhibitor of apoptosis protein; NAIP, neuronal apoptosis inhibitory protein; RING, really interesting new gene; UBA, ubiquitin-associated; UBC, ubiquitin-conjugating. 


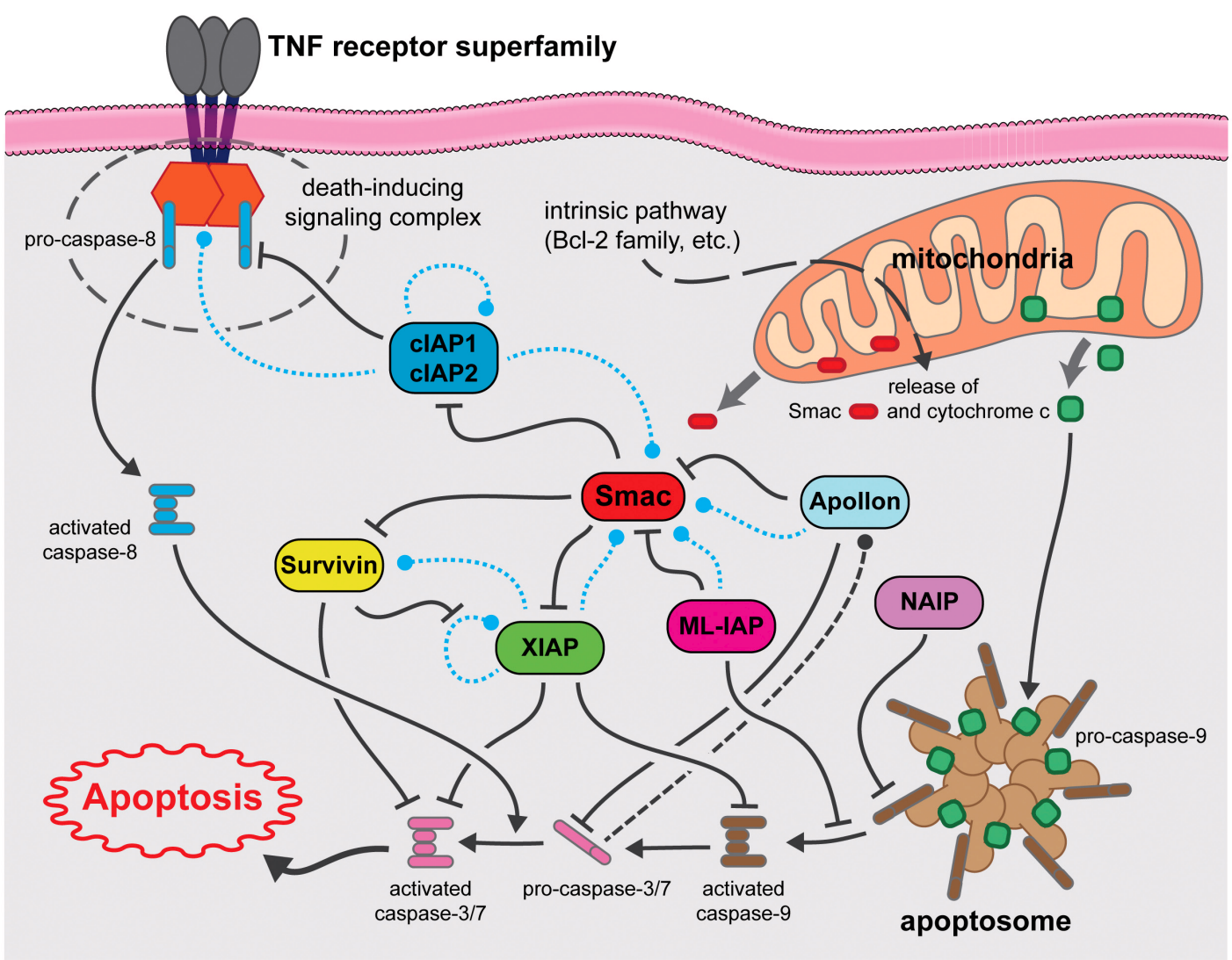

Figure 2. Schematic of pertinent inhibitor of apoptosis signaling pathways relevant to tumor cell survival and apoptosis. Dashed lines indicate potential degradative events (blue = ubiquitin-mediated, black = caspase-mediated). clAP1, cellular inhibitor of apoptosis protein 1; cIAP2, cellular inhibitor of apoptosis protein 2; ML-IAP, melanoma inhibitor of apoptosis protein; NAIP, neuronal apoptosis inhibitory protein; TNF, tumor necrosis factor.

Apollon is an extremely large protein (approximately $528 \mathrm{kDa}$ ) containing only one BIR domain that is thought to be membraneassociated as well as a C-terminal ubiquitin-conjugating (UBC) domain $^{43}$. It has been shown to attenuate apoptosis ${ }^{44-46}$ and to directly engage and interfere with both the second mitochondriaderived activator of caspases (Smac, discussed in greater detail below) and caspase- $9^{43,47}$. Others have confirmed that Apollon is involved in caspase-9-mediated apoptosis but that it can also regulate 553 and is essential in murine embryo development ${ }^{48}$.

The remaining four IAPs each possess three BIR domains in tandem and are the most studied members of the IAP family. Whilst XIAP and cIAP1 and 2 each contain a UBA and a RING domain, NAIP differs in that it has neither of these features but instead contains a "NACHT" domain and a C-terminal leucinerich repeat (LRR). The NACHT domain is so named because of its presence in NAIP, C2TA, HET-E, and TEP1, and it is predicted to be a nucleoside-triphosphatase (NTPase) domain ${ }^{49}$. Whilst its original discovery as the causative gene in SMA proved erroneous, NAIP has been shown to attenuate apoptosis in multiple models ${ }^{15,50,51}$. The main role of NAIP, however, appears to be in the regulation of innate immunity. Thus, NAIP, which is also part of the NOD-like receptor (NLR) family, is important for
NLRC4 inflammasome activation in response to certain bacterial ligands ${ }^{52-54}$.

cIAP1 and 2, whilst showing similar architecture to XIAP, also possess a caspase recruitment domain (CARD). Somewhat confusingly, however, the CARD of the cIAPs does not bind to caspases, but it appears to function in an auto-inhibitory manner to block the cIAP RING domain's E3 ubiquitin ligase activity ${ }^{55}$. The cIAPs are structurally very similar to each other with only a short linker sequence difference, are functionally redundant ${ }^{56,57}$, and are believed to have resulted from a recent evolutionary gene duplication. As with XIAP, they contain three BIR domains, and BIR1 is essential for binding to the TNFR adapter protein TRAF2 ${ }^{58,59}$. The third BIR domain (BIR3) in these three proteins, as well as the homologous BIR domain in ML-IAP, all potently bind to Smac, a negative regulator that will be discussed in much greater detail in subsequent sections of this review.

The cIAPs have been highly characterized in signaling events associated with a subset of TNFR superfamily members, called the death receptors (DRs), and it appears that their E3 ubiquitin ligase activity is especially pertinent in this regulation. DRs are categorized on the basis of the presence of a so-called death 
domain (DD). DDs are approximately 80-amino-acid alpha-helical structures that recruit adapter proteins capable of binding multiple other proteins in supramolecular complexes that regulate distinct signaling pathways based on composition (reviewed in 60-63). cIAPs recruited to these complexes can be involved in both degradative K48- and non-degradative K63-branched ubiquitination. Indeed, cIAP1 has been shown to control the levels of cIAP2 via degradative signaling, as depletion of cIAP1 results in a "rebound" of cIAP2 levels ${ }^{64}$. Similarly, levels of nuclear factorkappa B (NF- $\mathrm{KB})$-inducing kinase (NIK or MAP3K14) are tightly controlled by cIAPs, and these protein levels are almost undetectable when the E3 ubiquitin ligase activity of the proteins is available ${ }^{64-66}$. Much more significant, however, are the cIAPmediated non-degradative K63-branched ubiquitination and ensuing signaling. This ubiquitination of receptor-interacting protein 1 (RIP1) results in the formation of a signaling complex that can recruit further ubiquitin ligases and kinases that ultimately result in classical NF- $\kappa \mathrm{B}$ activation ${ }^{67,68}$ (and reviewed in 69). Indeed, recruitment of RIP1 to these complexes has led to the coining of the term "RIPoptosome" to describe them ${ }^{70-72}$. When cIAPs are absent-owing to genotoxic stress or chemical depletion with Smac mimetics (see below), for example - and the relevant receptor agonist is engaged, RIP1 is not degraded but forms a death signaling RIPoptosome ${ }^{72}$ with apoptosis effected via the apical caspases- 8 or -10 or both. Furthermore, in the absence of these caspases (or upon their inhibition), necroptosis can occur ${ }^{1,2}$. Necroptosis has been demonstrated to be dependent on RIP1 and specifically on its kinase activity (reviewed in 73). RIP1 phosphorylation of RIP3 results in the activation of mixed lineage kinase domain-like protein $(\mathrm{MLKL})^{74-76}$, which induces necroptotic death by rupturing of the plasma membrane $\mathrm{e}^{77-79}$.

In sum, the cIAPs are integral components of multiple signaling complexes emanating from TNFR superfamily members and, as a consequence, can regulate diverse cellular responses such as cell survival, apoptosis, and necroptosis via the RIPoptosome ${ }^{80,81}$.

XIAP is by far the most studied and highly characterized member of the IAP family. It is a potent inhibitor of apoptosis as judged by multiple model systems and techniques and has been clearly demonstrated to effect such inhibition due to direct binding of caspases $^{24}$. BIR2 and a short linker section between BIR1 and BIR2 are essential for binding and sequestration of the effector caspases -3 and $-7^{24,82-84}$, whilst BIR3 is crucial for binding to the apical caspase- $9^{85-87}$. As with the cIAPs, the BIR3 of XIAP also binds Smac, and this interaction results in caspase de-repression ${ }^{85,88-90}$. Thus, XIAP BIR3 binding of Smac has been shown to result in the release of active caspases from the XIAP protein complex and thus BIR3-Smac interaction is permissive for apoptosis induction $^{88,91}$. As such, Smac is not a direct activator of caspases, despite its name, but rather an "inhibitor of the inhibitor". Smac effects this displacement of factors from the BIR domains because of a four-amino-acid sequence of Ala-Val-Pro-Ile (AVPI) in Smac. Exposure of cells to this peptide motif can therefore sensitize cells to apoptotic stimuli or, in the case of cIAPs, result in their auto-degradation and subsequent switch from inhibitory to pro-apoptotic events from TNFRs. Owing to these effects, the AVPI tetrapeptide sequence has drawn much attention as a potential anticancer agent, and multiple Smac mimetics have been developed with a view to promoting apoptosis in tumor cells, where normal apoptotic signaling is perturbed. The current clinical progress of these agents is described in detail later.

In summary, the IAP family, whilst small in number, contains a series of diverse members with differing but somewhat overlapping biological roles. The most relevant of these roles in tumors is apoptosis inhibition, and the mechanisms governing how each member is involved are somewhat unique. The next section will discuss the roles of these proteins in cancer, and finally we will discuss the application of IAP inhibitors (Smac mimetics) as potential anti-cancer agents.

\section{Inhibitor of apoptosis and cancer}

The evasion of apoptosis is one of the hallmarks of cancer ${ }^{92-95}$, and, as noted above, the IAP family of proteins plays an important role in attenuating programmed cell death pathways, predominantly through modulation of the caspase cascade (extensively reviewed in 27,96-103). Furthermore, IAPs are often upregulated in cancers ${ }^{104}$ and are believed to underlie the resistance of many tumors to chemotherapeutics ${ }^{105,106}$. Ablation or antagonism of IAPs is therefore an attractive strategy to sensitize or re-sensitize tumor cells to apoptosis induced by other agents. The roles that the eight IAPs found in humans play in cancer are discussed below.

\section{NAIP}

NAIP (BIRC1) was first identified and named in 1995 by Roy et $a l .{ }^{16}$ as a potential modulator of the neuronal apoptotic pathway. As noted earlier, the main biological role for NAIP appears to be the regulation of innate immunity. Nevertheless, NAIP has been weakly linked to unfavorable prognosis in esophageal cancer $^{107}$, breast cancer ${ }^{108}$, prostate cancer ${ }^{109}$, and neuroblastoma ${ }^{110}$. The precise role of NAIP in the dysregulation of apoptosis in cancer and its value as a potential therapeutic target need further study.

\section{cIAP1, cIAP2, and XIAP (BIRC2, BIRC3, and BIRC4)}

As noted above, XIAP is a very potent binder and inhibitor of caspase-3. Accordingly, research by pharmaceutical companies has primarily focused on antagonizing this protein for oncology applications (reviewed in 111,112). cIAP1 and cIAP2 have also been implicated in cancer, and their role in the modulation of the $\mathrm{NF}-\mathrm{KB}$ signaling pathway has been investigated in detail ${ }^{113}$. It was also found that cIAP1 can protect cancer cells from the lethal effect of TNF through synergy with the MYC oncogene, thus driving tumorigenesis ${ }^{114-116}$. As cIAPs suppress TNF-induced cell death, it is likely that increased levels of cIAPs support tumor cell survival by modulating cellular responses to TNF. cIAPs and XIAP are additionally thought to contribute to cancer cell invasion and metastasis through their ability to drive NF- $\mathrm{BB}$ mediated expression of genes involved in cell motility, migration, and invasion ${ }^{117,118}$. Similarly, in lymphomas, cIAP2 is often found as a fusion protein with mucosa-associated lymphoid tissue 1 (MALT1), resulting in the activation of NF- $\kappa B$ signaling (reviewed in 119). IAPs have been shown to be overexpressed 
in many cell lines from the NCI60 panel as compared with the corresponding normal tissue ${ }^{120}$. XIAP overexpression in turn has been reported in childhood acute myeloid leukemia (AML) ${ }^{121}$, renal carcinoma ${ }^{122,123}$, multiple myeloma $(\mathrm{MM})^{124}$, and bladder cancers $^{125}$, and AML patients with low levels of expression of XIAP were shown to have a statistically significant survival advantage compared with those patients with higher levels ${ }^{120,126}$. In summary, the role and importance of these members of the IAP family of proteins in cancer have been extensively investigated and reviewed.

\section{Survivin}

Survivin (BIRC5) was first identified by Altieri et al. as an anti-apoptosis gene expressed in various cancer cells ${ }^{25,127}$. Survivin is an example of one of the earliest IAP proteins strongly implicated in oncogenesis ${ }^{128}$ and has been well established as a prognostic marker with a negative correlation on outcome in many cancers $^{129-133}$ (reviewed in 134-138). Consistent with this, excessive levels of Survivin inhibit both intrinsic and extrinsic pathways of apoptosis ${ }^{25,139-141}$. Of note, however, Survivin is only a weak apoptosis inhibitor at physiological concentrations and may in fact exert anti-apoptotic activity through stabilization of $\mathrm{XIAP}^{142}$. Recent studies have shown Survivin to be an important regulator of cell division, and this appears to be its main biological function ${ }^{5-7,143}$. The role of Survivin in cancer has recently been reviewed extensively ${ }^{144-147}$. Therapeutic targeting of Survivin has been mostly confined to non-small-molecule strategies ${ }^{148,149}$ and repression of protein translation ${ }^{150-152}$ (reviewed in 153), and only recently have small-molecule inhibitors been reported ${ }^{154,155}$.

\section{Apollon}

Apollon (BIRC6, the human homolog of murine BRUCE) was first identified in 1999 by Chen et al. ${ }^{32}$ as a marker in brain and ovarian cancer cell lines that is linked to resistance to various anticancer drugs. A number of subsequent studies have concluded that elevated levels of Apollon are linked to poor prognosis in a range of cancers, such as leukemia ${ }^{156,157}$, breast ${ }^{158}$, neuroblastoma ${ }^{159}$, prostate $^{160-162}$, lung ${ }^{163}$, ovarian ${ }^{164}$, colorectal $^{165}$, hepatocellular ${ }^{166}$, and head and neck ${ }^{167}$ cancers. It is largely understood that the role of Apollon as an oncogene is centered on its role in modulating Smac and caspase-9 levels, where overexpression of Apollon leads to increased silencing of apoptosis through Smac degradation as well as to attenuation of the caspase cascade by targeting caspase-9 for ubiquitination and subsequent degradation ${ }^{43,45,47}$. Based on these predictive findings, the role of Apollon as a therapeutic target has been evaluated in a number of studies using functional genomic approaches, since no appropriate smallmolecule tool has yet been developed ${ }^{158,159,166,168}$. Undoubtedly, the development of potent and selective small-molecule antagonists to Apollon will allow detailed elucidation of its potential as a therapeutic target in oncology.

\section{ML-IAP}

ML-IAP (BIRC7, also known as Livin or KIAP) was first identified as a member of the IAP family because of its single BIR domain ${ }^{33,35}$. The ML-IAP BIR domain is also responsible for apoptosis inhibition, and small molecules that target this region could potentially re-sensitize cancer cells to chemotherapeutics.
In particular, the RING domain of ML-IAP has been shown to function as an E3 ubiquitin ligase facilitating the ubiquitination and subsequent degradation of itself ${ }^{169,170}$ and, more importantly, of Smac ${ }^{170}$, the natural caspase antagonist that modulates apoptotic signaling. Thus, inhibition of ML-IAP leads to a direct increase of Smac and a re-sensitization of cells to apoptotic stimuli. Both protein and mRNA levels of ML-IAP are low to undetectable in most adult tissues ${ }^{171}$ but are highly expressed in several cancers ${ }^{33,171-179}$, including various lung cancers, melanoma, liver cancer, glioblastoma, and oral squamous cell carcinoma. This protein is also highly expressed in renal cell carcinoma ${ }^{180,181}$, and this is why the original name of kidney IAP (KIAP) was coined. ML-IAP maps to chromosome $20 \mathrm{q} 13$, a region frequently implicated in the mutagenic etiology of lung cancers ${ }^{33}$. ML-IAP levels have been shown to be highly relevant as a prognostic biomarker in lung ${ }^{172,173,182,183}$ and other ${ }^{174,175,177,179,180,184-187}$ cancers. These studies have consistently reported that high ML-IAP expression correlates with a poor outcome but that lower levels predict a more favorable prognosis. A number of recent studies have clearly shown the considerable therapeutic potential of ML-IAP inhibition to treat cancer. A wealth of data has been presented in cellular contexts ${ }^{188-195}$ as well as in xenograft studies ${ }^{196,197}$. In particular, the mouse xenograft studies by Chen et al. ${ }^{196}$ and the cell-line-based work by Zhuang et al. ${ }^{198}$ showed a substantial benefit gained from BIRC7 gene ablation in models of lung cancer. However, all of these studies inhibited ML-IAP through RNA knockdown approaches because of the unavailability of a selective and potent smallmolecule antagonist. Recently, however, potent and uniquely selective ML-IAP inhibitors have been reported, which will help more comprehensive elucidation of the role of ML-IAP in cancers ${ }^{199}$.

\section{ILP-2}

ILP-2 (IAP-like protein-2 or BIRC8) was originally detected only in the testis and lymphoblastoid cells ${ }^{36}$. However, some recent work has established a tenuous link to breast cancer ${ }^{200}$, and it will be of interest to see whether this link gains further support to establish ILP-2 as a novel biomarker in human malignancies as well as a potential target for therapy.

\section{Inhibitor of apoptosis inhibitor development for cancer therapeutics}

In the mid-1990s, it was shown that the BIR domains were necessary and responsible for the anti-apoptotic and caspasesuppressing activity of the IAP proteins ${ }^{10,14,84}$. With the subsequent discovery of the endogenous IAP ligand Smac in $2000^{88,201}$, the path toward the development of small-molecule inhibitors of the IAPs unfolded. Historically, however, the development of smallmolecule inhibitors of such PPIs has been quite difficult. Most of these interactions are devoid of the classic druggable binding pockets (about 300-500 $\AA^{2}$ ) with which most drug discovery scientists are familiar ${ }^{202}$. Rather, these PPIs typically derive their binding energy from a large number of intermolecular interactions along a relatively flat and large (about 1,000-2,000 $\AA^{2}$ ) surface.

It was a critical observation made by Xiadong Wang et al. regarding the loss of Smac activity upon the addition of a glutathione s-transferase (GST) fusion to its $\mathrm{N}$-terminus that paved 
the way for the current crop of Smac mimetics ${ }^{203}$. Mutation studies further confirmed the importance of the posttranslationally processed and flexible N-terminus of mature Smac. Perhaps equally important was the contribution from Fesik et al. that year, generating the first nuclear magnetic resonance structure of truncated Smac bound to one of the IAPs, XIAP BIR3 ${ }^{89}$. Specifically, four residues, AVPI, that bind to a surface groove on the IAP BIR domains proved indispensable for activity. As shown in Figure 3, there exists in the IAP BIR domains a negatively charged cleft of perfect size to accept the alanine. Furthermore, the proline of Smac allows for a crucial reverse turn feature to maintain close contacts with the binding site. These are two key elements represented in nearly all of the reported IAP inhibitors. Early on, several groups showed that synthetic oligopeptides (4-9-mers) exhibit better binding affinity than native Smac for XIAP BIR3 and are notable for their apoptosis-inducing ability $^{204-206}$. These oligopeptides served an important role as a drug discovery proof-of-concept: that mimicking a small portion of Smac is a viable strategy to target the IAPs. Subsequent reports took this concept a step further and focused on developing more drug-like peptidomimetics of the N-terminal AVPI tetrapeptide binding motif to disrupt the IAP-caspase PPI, and thus far this has proven to be the most popular and successful tactic. The first true medicinal chemistry work reported by Fesik et al. in $2004^{207}$ laid the groundwork for the advances that would follow in subsequent years, and, also in 2004, seminal work from Wang and Harran showed that a small-molecule Smac mimetic could potentiate TNF-induced and TNF-related apoptosis-inducing ligand (TRAIL)-induced apoptosis ${ }^{208}$. A summary of the collective structure-activity-relationship (SAR) conclusions from Smac mimetic medicinal chemistry work is shown in Figure 4.

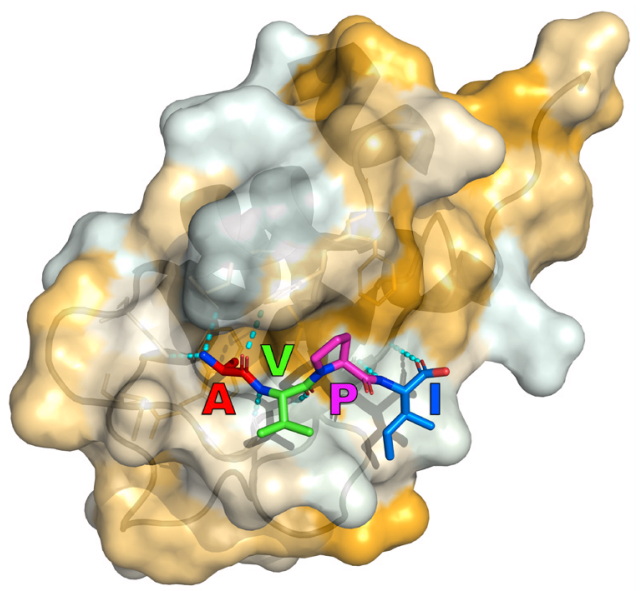

Figure 3. Crystal structure of Ala-Val-Pro-Ile (AVPI), a Smac core motif, bound to the BIR2 domain of XIAP (Protein Data Bank code $=\mathbf{4 J 4 6 )}$. Binding is strongly driven by hydrogen-bond formation (dashed cyan lines) and non-polar interactions. Hydrophobic surface properties of the BIR2 domain are shown in yellow. Note that the color scheme of the tetrapeptide sequence is maintained for the subsequent figure.
A number of research groups from both academia and industry have initiated programs in the space since these early discoveries, focusing on Smac mimetics ${ }^{66,199,209-256}$ (also reviewed in 257,258). Some of these compounds remain in pre-clinical testing, whereas others have entered but are no longer active in clinical trials. Our laboratories are currently testing a series of Smac mimetics developed by us at Sanford Burnham Prebys Medical Discovery Institute. A representative compound with encouraging preclinical data in several cancer cell lines is shown in Figure $5^{199}$. SBI-0636457 has demonstrated potent cell-killing effects in several subtypes of breast, ovarian, and prostate cancer cell lines but only when the DR ligand TRAIL or another such apoptosis inducer is co-administered. Furthermore, SBI-0636457 administered as a single agent exhibited no toxicity to normal human fibroblasts.

Bivalent Smac mimetics take advantage of the homodimeric nature of native Smac and are able to bind both the BIR2 and the BIR3 domains. The consequence of this improved binding mode is poorer drug-like properties, as the Smac mimetics must adopt a larger molecular size in order to access both binding sites. Impressive binding data $\left(\mathrm{K}_{\mathrm{d}}=300 \mathrm{pM}\right.$ for the BIR2-BIR3

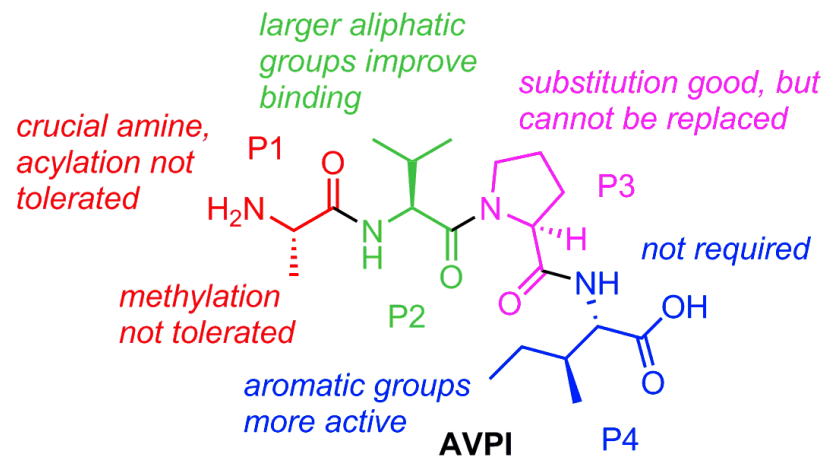

Figure 4. Structure-activity relationship of Smac mimetics is largely based on the original amino acid positions from the AlaVal-Pro-Ile (AVPI) peptide.
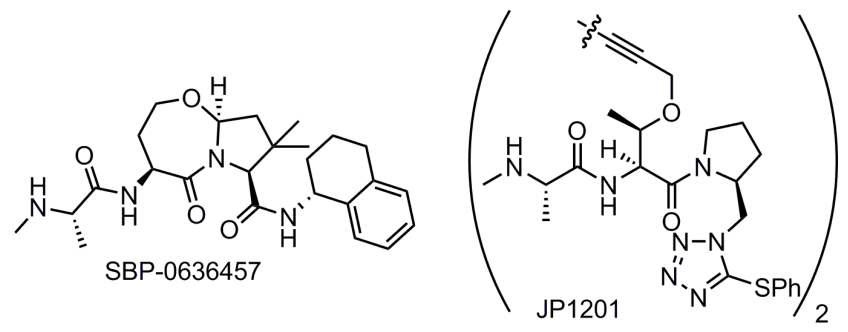

Figure 5. Structures of the Smac mimetic SBP-0636457 being developed by Sanford Burnham Prebys Medical Discovery Institute and the bivalent agent JP1201 from Joyant Pharmaceuticals. 
construct) were observed for the first reported bivalent IAP inhibitor (JP1201) from the Wang and Harran labs (Figure 5) ${ }^{208}$.

\section{Current clinical status of inhibitor of apoptosis inhibitors in oncology}

In the US, several monovalent Smac mimetic compounds and one bivalent compound have entered the clinic and are still active in clinical trials (Figure 6). All of the compounds for which clinical data have been reported so far demonstrated generally favorable safety profiles in phase I, and amylase/lipase elevation, alanine and aspartate transaminase (ALT and AST) elevation, cytokine release syndrome (CRS), and Bell's palsy were the dose-limiting serious adverse events ${ }^{112}$. Of note, however, the Bell's palsy toxicity has been observed only with bivalent and not with monovalent Smac mimetics. It has been suggested that CRS may result from the Smac mimetic-induced degradation of cIAP1 and the consequent activation of the NF- $\kappa \mathrm{B}$ pathway and an autocrine/paracrine TNF signaling loop. Other possibilities exist, however, as work from Silke and Vaux suggests that triple knockdown of cIAP1, cIAP2, and XIAP results in a hyperactive inflammatory state through still-undefined mechanisms (reviewed in 259). While TNF release potentially enables the efficacy of Smac mimetics as single agents in cancer therapy, the possibility of inducing a "cytokine storm" may render this approach less desirable compared with a combination approach (TNFR agonists + Smac mimetics), especially for indications outside of cancer ${ }^{260,261}$. Indeed, Smac mimetics have demonstrated synergy with other modes of treatment, including cytotoxic agents (that is, carboplatin ${ }^{262}$ and paclitaxel ${ }^{263}$ ), radiation therapy ${ }^{264}$, and cell DR ligands (TRAIL analogues) ${ }^{265}$. These synergies are well defined in pre-clinical models, but, so far, they have been less successful in clinical settings (see below). In general, any treatment that stresses the cells, such as standard chemotherapy or radiation therapy, and induces either intrinsic or extrinsic apoptosis via upstream activation could be combined with the caspase-liberating effect of IAP inhibitors to kill cancer cells. Although a number of Smac mimetics have already entered clinical trials, we shall focus our discussion here on those for which trials are currently active (Table 1 ).

\section{Birinapant}

Birinapant is a bivalent Smac mimetic developed by Tetralogic Pharmaceuticals and currently owned by Medivir. Owing to the size of this molecule, only administration by intravenous line has been reported for birinapant, both as a single agent and in combination with several chemotherapeutics (azacitidine, gemcitabine, irinotecan, and conatumumab) ${ }^{266}$. The data released so far have been lackluster, and poor efficacy has been demonstrated in the completed studies. In NCT01681368, no complete nor partial response was observed in solid tumors of 11 patients, and accrual was terminated for lack of detected clinical benefit ${ }^{267}$. Good, though muted, news came in the phase I/II trial NCT01188499. In patients with metastatic colorectal cancer who previously failed irinotecan treatment, the combination of irinotecan with birinapant resulted in disease stabilization in $62 \%$ of patients, higher than the $41 \%$ rate shown by the recently approved kinase inhibitor regorafenib ${ }^{268}$. The other silver lining for these results is that the response rate as measured by tumor regression was higher, albeit small, at $8 \%$ compared with regorafenib at $1 \%{ }^{269}$ and that the enrolled patients had previously failed all available treatments. When comparing these two sets of trial data, one must bear in mind that the regorafenib data come from an earlier and much larger phase III trial. The failure of birinapant versus placebo in a study (NCT02147873) investigating its capacity to treat myelodysplastic syndrome resulted in the folding of Tetralogic and transfer of assets to Medivir, where trials are ongoing ${ }^{270}$. Given the previous failures, it will be critical to see favorable clinical outcomes for the conatumumab (DR5 agonist) combination therapy trial (NCT01940172) as well as the trial with pembrolizumab (PD-1 inhibitor) as co-treatment (NCT02587962). CRS has so far proven to be a relatively minor adverse event in patients who received birinapant, and only $10 \%$ of patients reported low-grade symptoms ${ }^{266}$.

\section{LCL161}

LCL161 is a monovalent IAP inhibitor developed by Novartis that is currently in active clinical trials and has also shown generally good safety up to a $1,800 \mathrm{mg}$ dose; CRS was the major

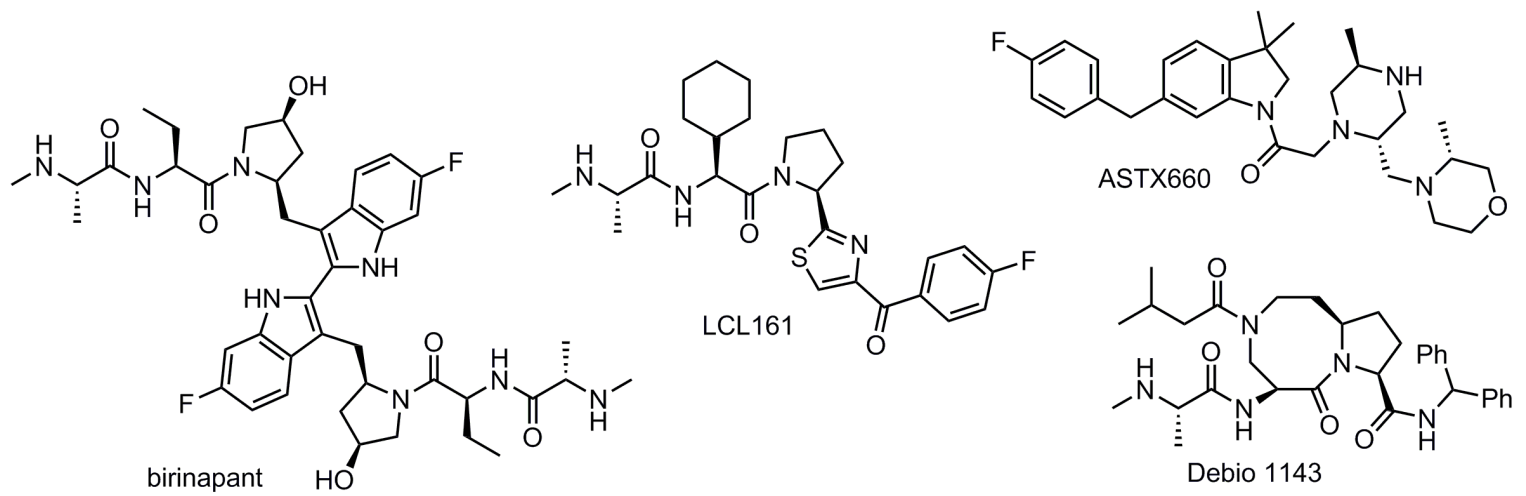

Figure 6. Chemical structures of inhibitor of apoptosis inhibitor compounds in active clinical trials. 
Table 1. Ongoing clinical trials with inhibitor of apoptosis inhibitors.

\begin{tabular}{|c|c|c|c|c|c|}
\hline $\begin{array}{l}\text { NCT } \\
\text { number }\end{array}$ & Phase & Title & Interventions & Conditions & Sponsor \\
\hline 02587962 & $\mid / I I$ & $\begin{array}{l}\text { Dose escalation study of birinapant and } \\
\text { pembrolizumab in solid tumors }\end{array}$ & $\begin{array}{l}\text { Birinapant, } \\
\text { pembrolizumab }\end{array}$ & Solid tumors & $\begin{array}{l}\text { TetraLogic } \\
\text { (Medivir) }\end{array}$ \\
\hline 02756130 & II & $\begin{array}{l}\text { Proof-of-concept study of birinapant in combination } \\
\text { with platinum-based chemotherapy in subjects with } \\
\text { high-grade serous carcinomas }\end{array}$ & $\begin{array}{l}\text { Birinapant, paclitaxel, } \\
\text { carboplatin }\end{array}$ & $\begin{array}{l}\text { Advanced newly } \\
\text { diagnosed or } \\
\text { recurrent high-grade } \\
\text { serous carcinomas }\end{array}$ & $\begin{array}{l}\text { TetraLogic } \\
\text { (Medivir) }\end{array}$ \\
\hline 01486784 & $\mid / I I$ & $\begin{array}{l}\text { A phase I-II open-label non-randomized study } \\
\text { using TL32711 for patients with acute myelogenous } \\
\text { leukemia, myelodysplastic syndrome, and acute } \\
\text { lymphoblastic leukemia }\end{array}$ & Birinapant & $\begin{array}{l}\text { Acute myelogenous } \\
\text { leukemia }\end{array}$ & $\begin{array}{l}\text { Tetralogic } \\
\text { (Medivir) }\end{array}$ \\
\hline 01934634 & । & $\begin{array}{l}\text { Phase I trial of LCL161 and gemcitabine plus } \\
\text { nab-paclitaxel in metastatic pancreatic cancer }\end{array}$ & $\begin{array}{l}\text { LCL161, gemcitabine, } \\
\text { nab-paclitaxel }\end{array}$ & $\begin{array}{l}\text { Metastatic } \\
\text { pancreatic cancer }\end{array}$ & Novartis \\
\hline 01955434 & II & $\begin{array}{l}\text { SMAC mimetic LCL } 161 \text { alone or with } \\
\text { cyclophosphamide in treating relapsed or refractory } \\
\text { multiple myeloma }\end{array}$ & $\begin{array}{l}\text { LCL161, } \\
\text { cyclophosphamide }\end{array}$ & $\begin{array}{l}\text { Recurrent and } \\
\text { refractory plasma } \\
\text { cell myeloma }\end{array}$ & Mayo Clinic \\
\hline 02649673 & $1 / I I$ & $\begin{array}{l}\text { LCL161 plus topotecan for patients with relapsed/ } \\
\text { refractory small cell lung cancer and select } \\
\text { gynecologic malignancies }\end{array}$ & LCL161, topotecan & $\begin{array}{l}\text { Small cell lung } \\
\text { cancer, ovarian } \\
\text { cancer }\end{array}$ & Novartis \\
\hline 02098161 & II & $\begin{array}{l}\text { Phase II LCL-161 in patients with primary } \\
\text { myelofibrosis, post-polycythemia vera } \\
\text { myelofibrosis, or post-essential thrombocytosis } \\
\text { myelofibrosis }\end{array}$ & LCL-161 & Leukemia & Novartis \\
\hline 02890069 & I & $\begin{array}{l}\text { A study of PDR001 in combination with LCL161, } \\
\text { everolimus, or panobinostat }\end{array}$ & $\begin{array}{l}\text { LCL161, PDR001, } \\
\text { everolimus, } \\
\text { panobinostat }\end{array}$ & $\begin{array}{l}\text { Colorectal cancer, } \\
\text { non-small cell lung } \\
\text { carcinoma, triple- } \\
\text { negative breast } \\
\text { cancer }\end{array}$ & Novartis \\
\hline 02022098 & $\mid / I I$ & $\begin{array}{l}\text { Debio 1143-201 dose-finding and efficacy phase } \\
\text { I/II trial }\end{array}$ & $\begin{array}{l}\text { Debio } 1143, \text { cisplatin, } \\
\text { radiotherapy }\end{array}$ & $\begin{array}{l}\text { Squamous cell } \\
\text { carcinoma of the } \\
\text { head and neck }\end{array}$ & Debiopharm \\
\hline 02503423 & $I / I I$ & $\begin{array}{l}\text { Phase I-II study of ASTX660 in subjects with } \\
\text { advanced solid tumors and lymphomas }\end{array}$ & ASTX660 & $\begin{array}{l}\text { Solid tumors, } \\
\text { lymphoma }\end{array}$ & Astex \\
\hline
\end{tabular}

adverse event ${ }^{271}$. Despite the encouraging safety profile, early results in a phase I trial (NCT01098838) indicate no objective response from LCL161 single-agent treatment in patients with solid tumors, and the best response was stable disease observed in $19 \%$ of patients. These early trial data indicate that the use of Smac mimetics as a monotherapy may be limited by the amount of CRS elicited by the drug or, more broadly, the class of drugs ${ }^{272}$. Results from the phase II study (NCT01617668) testing LCL161 in combination with paclitaxel in triple-negative breast cancer indicate that this approach may circumvent the CRS issues, as it was a serious adverse event for only $0.94 \%$ of patients ${ }^{273}$. It must be noted that it is not clear why the LCL161 plus paclitaxel treatment did not elicit the same CRS response as observed in the phase I study of LCL161 single-agent treatment at the same $1,800 \mathrm{mg}$ dose. The study also revealed a $38 \%$ pathological complete response rate versus $17 \%$ for paclitaxel alone in a select patient population (for details of the study design, see 274).
Interestingly, the increased pathological response rate is observed in a subgroup of patients who showed an elevated TNFalpha/RIP1 gene signature prior to treatment. These data are encouraging and also help to further the idea of the need for a combination therapy with Smac mimetics. More recently, LCL161 has been tested in combination with cyclophosphamide in MM (NCT01955434). The combination of cyclophosphamide with LCL161 resulted in progression-free survival of 10 months in patients with relapsed/refractory MM $^{275}$. LCL161 was also shown to be effective in a transgenic mouse myeloma model, appearing to act via an immunological mechanism ${ }^{275}$. Chesi et al. ${ }^{275}$ demonstrated that the antagonism of IAPs by LCL161 does not result in direct killing of tumor cells, but rather it induces a tumor-cell autonomous type 1 interferon response. This results in a strong inflammatory response that ultimately leads to phagocytosis of the cancer cells. Intriguingly, the authors further show that LCL161 combination with PD-1 blockade 
was curative of all mice that completed 2 weeks of treatment ${ }^{275}$. Expanding on these findings is recent evidence that immune checkpoint blockade combined with Smac mimetics is efficacious in pre-clinical models of glioblastoma ${ }^{276}$. As such, the immune regulatory roles of IAPs may also be of much therapeutic relevance.

\section{Debio 1143}

Debio 1143 is another monovalent Smac mimetic in ongoing clinical trials for a number of different malignancies. It was developed in its early stages by the Wang group at the University of Michigan and later at Ascenta Therapeutics, ultimately being licensed to Debiopharm. Phase I safety studies were in line with the previously reported Smac mimetics reported above, when tested as a monotherapy: generally mild adverse events with a highest tested dose of $900 \mathrm{mg}^{277}$. On-target pharmacodynamic modulation was achieved at doses above $80 \mathrm{mg}$, as measured by cIAP1 degradation. Preliminary efficacy data from the trial indicated that $20 \%$ of patients exhibited stable disease as the best response. With the encouraging safety data, a phase I/II trial (NCT02022098) with cisplatin and radiotherapy as co-treatment was undertaken for squamous cell carcinoma of the head and neck, and the expected completion date is 2019 .

\section{ASTX660}

UK-based Astex Pharmaceuticals recently initiated their own phase I/II trial (NCT02503423) for the small-molecule ASTX660 for solid tumors and lymphomas. Envisioning ASTX660 as part of a two-pronged cell death approach, Astex screened a number of breast, colorectal, ovarian, leukemia, and melanoma cell lines for their response to monotherapy versus co-treatment with TNF-alpha ${ }^{278}$. It will be interesting to see how well the pre-clinical data correlate with the clinical data expected in 2018.

While the ability of the reported Smac mimetics to induce cancer cell death in pre-clinical models was exciting and held much promise, so far the first-in-human studies have presented lackluster results. Several compounds that were able to induce cancer cell death and thus partial or complete remission in tissue culture and animal studies have not had similar success in trials as a monotherapy. However, given the promising clinical pharmacodynamics and safety data, further research and development efforts are certainly warranted.

\section{Conclusions and future work}

As detailed above, the IAPs are at the nexus of cancer cell survival and, conversely, apoptosis. As such, the inhibition of pertinent family members would be expected to afford a valuable therapeutic intervention strategy for cancers, as these diseases are largely conditions of increased proliferation and impaired apoptosis. As often occurs, however, the reality has proven vastly more complicated than first envisioned. As detailed above, although Smac mimetics are safe and well tolerated, they have shown little single-agent activity in clinical trials. Intuitive, yet not extensively preclinically verified, combinations of IAP antagonists such as Smac mimetics with standard-of-care chemotherapeutics have likewise proven unfruitful to most degrees, although there have been some responses, as described above. Perhaps most encouraging have been pre-clinical studies showing that IAP antagonists are potent sensitizers to certain TNFR family agonists ${ }^{64,199,208,279-283}$. Additionally, it has been shown that this can be effected not only by the natural ligands themselves but also by agonistic antibodies to TRAIL receptors developed by several pharmaceutical companies ${ }^{284-288}$. Targeting TRAIL receptors with simultaneous IAP inhibition not only is toxic to cancer cells but also leaves non-transformed cells untouched, a "holy grail" of anti-cancer therapy. Expanding on these observations are studies by Beug et al., who show that concomitant induction of an immune response when IAPs are inhibited can produce a profound tumor regression in animal models ${ }^{289}$. Indeed, the use of Smac mimetics and attenuated oncolytic viruses as an anti-cancer strategy has shown promising results in some models ${ }^{290}$. As such, the notion of targeted activation of certain TNFRs in combination with IAP inhibition is a potential potent intervention point in many cancers. Already, clinical trials of just such a combination are underway (discussed above), and the results should further assist in our progress toward more targeted therapies using these phenomena.

In sum, whilst the clinical application of IAP antagonists has to date not produced the panacea desired, the ongoing development of next-generation agents and pertinent combinations bodes well for the future. "Inhibiting the inhibitors" ${ }^{291}$ may soon be a viable anti-cancer strategy.

\section{Competing interests}

The authors declare that they have no competing interests.

\section{Grant information}

This work was supported by National Institutes of Health grant R01CA195227 to DF and NDPC.

The funders had no role in study design, data collection and analysis, decision to publish, or preparation of the manuscript. 
1. F Degterev A, Huang Z, Boyce M, et al:: Chemical inhibitor of nonapoptotic cell death with therapeutic potential for ischemic brain injury. Nat Chem Biol. 2005; 1(2): 112-9.

PubMed Abstract | Publisher Full Text | F1000 Recommendation

2. Geserick P, Hupe M, Moulin M, et al.: Cellular IAPs inhibit a cryptic CD95-induced cell death by limiting RIP1 kinase recruitment. J Cell Biol. 2009; 187(7): 103754 .

PubMed Abstract | Publisher Full Text | Free Full Text

3. Silke J, Brink R: Regulation of TNFRSF and innate immune signalling complexes by TRAFs and cIAPs. Cell Death Differ. 2010; 17(1): 35-45. PubMed Abstract | Publisher Full Text

4. Gentle IE, Moelter I, Lechler N, et al.: Inhibitors of apoptosis proteins (IAPs) are required for effective T-cell expansion/survival during antiviral immunity in mice. Blood. 2014; 123(5): 659-68.

PubMed Abstract | Publisher Full Text

5. Uren AG, Beilharz T, O'Connell MJ, et al:: Role for yeast inhibitor of apoptosis (IAP)-like proteins in cell division. Proc Natl Acad Sci U S A. 1999; 96(18): 10170-5.

PubMed Abstract | Publisher Full Text | Free Full Text

6. Uren AG, Wong L, Pakusch M, et al.: Survivin and the inner centromere protein INCENP show similar cell-cycle localization and gene knockout phenotype. Curr Biol. 2000; 10(21): 1319-28.

PubMed Abstract | Publisher Full Text

7. Silke J, Vaux DL: Two kinds of BIR-containing protein - inhibitors of apoptosis or required for mitosis. J Cell Sci. 2001; 114(Pt 10): 1821-7. PubMed Abstract

8. Crook NE, Clem RJ, Miller LK: An apoptosis-inhibiting baculovirus gene with a zinc finger-like motif. $J$ Virol. 1993; 67(4): 2168-74. PubMed Abstract | Free Full Text

9. Birnbaum MJ, Clem RJ, Miller LK: An apoptosis-inhibiting gene from a nuclear polyhedrosis virus encoding a polypeptide with $\mathrm{Cys} / \mathrm{His}$ sequence motifs. $J$ Virol. 1994; 68(4): 2521-8. PubMed Abstract | Free Full Text

10. Clem RJ, Miller LK: Control of programmed cell death by the baculovirus genes p35 and iap. Mol Cell Biol. 1994; 14(8): 5212-22. PubMed Abstract | Publisher Full Text | Free Full Text

11. Huang $Q$, Deveraux QL, Maeda S, et al:: Cloning and characterization of an inhibitor of apoptosis protein (IAP) from Bombyx mori. Biochim Biophys Acta. 2001; 1499(3): 191-8.

PubMed Abstract | Publisher Full Text

12. Fraser AG, James C, Evan GI, et al:: Caenorhabditis elegans inhibitor of apoptosis protein (IAP) homologue BIR-1 plays a conserved role in cytokinesis. Curr Biol. 1999; 9(6): 292-301.

PubMed Abstract | Publisher Full Text

13. Yaraghi Z, Korneluk RG, MacKenzie A: Cloning and characterization of the multiple murine homologues of NAIP (neuronal apoptosis inhibitory protein). Genomics. 1998; 51(1): 107-13.

PubMed Abstract | Publisher Full Text

14. Hay BA, Wassarman DA, Rubin GM: Drosophila homologs of baculovirus inhibitor of apoptosis proteins function to block cell death. Cell. 1995; 83(7): 1253-62.

PubMed Abstract | Publisher Full Text

15. Liston P, Roy N, Tamai K, et al.: Suppression of apoptosis in mammalian cells by NAIP and a related family of IAP genes. Nature. 1996; 379(6563): 349-53. PubMed Abstract | Publisher Full Text

16. Roy N, Mahadevan MS, McLean M, et al:: The gene for neuronal apoptosis inhibitory protein is partially deleted in individuals with spinal muscular atrophy. Cell. 1995; 80(1): 167-78.

PubMed Abstract | Publisher Full Tex

17. Rothe M, Wong SC, Henzel WJ, et al:: A novel family of putative signal transducers associated with the cytoplasmic domain of the $75 \mathrm{kDa}$ tumor necrosis factor receptor. Cell. 1994; 78(4): 681-92. PubMed Abstract | Publisher Full Text

18. Rothe M, Pan MG, Henzel WJ, et al:: The TNFR2-TRAF signaling complex contains two novel proteins related to baculoviral inhibitor of apoptosis proteins. Cell. 1995; 83(7): 1243-52. PubMed Abstract | Publisher Full Text

19. Shu HB, Takeuchi M, Goeddel DV: The tumor necrosis factor receptor 2 signal transducers TRAF2 and c-IAP1 are components of the tumor necrosis factor receptor 1 signaling complex. Proc Natl Acad Sci U S A. 1996; 93(24): 13973-8. PubMed Abstract | Publisher Full Text | Free Full Text

20. Wang CY, Mayo MW, Korneluk RG, et al:: NF-kappaB antiapoptosis: induction of TRAF1 and TRAF2 and c-IAP1 and c-IAP2 to suppress caspase-8 activation. Science. 1998; 281(5383): 1680-3. PubMed Abstract | Publisher Full Text

21. Salvesen GS, Duckett CS: IAP proteins: blocking the road to death's door. Nat Rev Mol Cell Biol. 2002; 3(6): 401-10. PubMed Abstract | Publisher Full Text
22. Uren AG, Pakusch M, Hawkins CJ, et al: Cloning and expression of apoptosis inhibitory protein homologs that function to inhibit apoptosis and/or bind tumor necrosis factor receptor-associated factors. Proc Natl Acad Sci U S A. 1996; 93(10): 4974-8.

PubMed Abstract | Publisher Full Text | Free Full Text

23. Hawkins CJ, Uren AG, Hacker G, et al:: Inhibition of interleukin 1 betaconverting enzyme-mediated apoptosis of mammalian cells by baculovirus IAP. Proc Natl Acad Sci U S A. 1996; 93(24): 13786-90. PubMed Abstract | Publisher Full Text | Free Full Text

24. Deveraux QL, Takahashi R, Salvesen GS, et al:: X-linked IAP is a direct inhibitor of cell-death proteases. Nature. 1997; 388(6639): 300-4. PubMed Abstract | Publisher Full Text

25. Ambrosini G, Adida C, Altieri DC: A novel anti-apoptosis gene, survivin, expressed in cancer and lymphoma. Nat Med. 1997; 3(8): 917-21. PubMed Abstract | Publisher Full Text

26. Deveraux QL, Roy N, Stennicke HR, et al:: IAPs block apoptotic events induced by caspase-8 and cytochrome $c$ by direct inhibition of distinct caspases. EMBO J. 1998; 17(8): 2215-23.

PubMed Abstract | Publisher Full Text | Free Full Text

27. LaCasse EC, Baird S, Korneluk RG, et al:: The inhibitors of apoptosis (IAPs) and their emerging role in cancer. Oncogene. 1998; 17(25): 3247-59. PubMed Abstract | Publisher Full Text

28. Duckett CS, Nava VE, Gedrich RW, et al:: A conserved family of cellular genes related to the baculovirus iap gene and encoding apoptosis inhibitors. $E M B O \mathrm{~J}$ 1996; 15(11): 2685-94.

PubMed Abstract | Free Full Text

29. Adida C, Crotty PL, McGrath J, et al.: Developmentally regulated expression of the novel cancer anti-apoptosis gene survivin in human and mouse differentiation. Am J Pathol. 1998; 152(1): 43-9. PubMed Abstract | Free Full Text

30. Ambrosini G, Adida C, Sirugo G, et al.: Induction of apoptosis and inhibition of cell proliferation by survivin gene targeting. J Biol Chem. 1998; 273(18): 11177-82. PubMed Abstract | Publisher Full Text

31. Hauser HP, Bardroff M, Pyrowolakis G, et al:: A giant ubiquitin-conjugating enzyme related to IAP apoptosis inhibitors. J Cell Biol. 1998; 141(6): 1415-22. PubMed Abstract | Publisher Full Text | Free Full Text

32. Chen Z, Naito M, Hori S, et al:: A human IAP-family gene, apollon, expressed in human brain cancer cells. Biochem Biophys Res Commun. 1999; 264(3): 847-54. PubMed Abstract | Publisher Full Text

33. Vucic D, Stennicke HR, Pisabarro MT, et al.: ML-IAP, a novel inhibitor of apoptosis that is preferentially expressed in human melanomas. Curr Biol. 2000; 10(21): 1359-66.

PubMed Abstract | Publisher Full Text

34. Lin JH, Deng G, Huang Q, et al:: KIAP, a novel member of the inhibitor of apoptosis protein family. Biochem Biophys Res Commun. 2000; 279(3): 820-31. PubMed Abstract | Publisher Full Text

35. Kasof GM, Gomes BC: Livin, a novel inhibitor of apoptosis protein family member. J Biol Chem. 2001; 276(5): 3238-46.

PubMed Abstract | Publisher Full Text

36. Richter BW, Mir SS, Eiben LJ, et al:: Molecular cloning of ILP-2, a novel member of the inhibitor of apoptosis protein family. Mol Cell Biol. 2001; 21(13): 4292-301. PubMed Abstract | Publisher Full Text | Free Full Text

37. Lagace M, Xuan JY, Young SS, et al:: Genomic organization of the X-linked inhibitor of apoptosis and identification of a novel testis-specific transcript. Genomics. 2001; 77(3): 181-8. PubMed Abstract | Publisher Full Text

38. Chu ZL, McKinsey TA, Liu L, et al:: Suppression of tumor necrosis factorinduced cell death by inhibitor of apoptosis c-IAP2 is under NF-kappaB control. Proc Natl Acad Sci U S A. 1997; 94(19): 10057-62. PubMed Abstract | Publisher Full Text | Free Full Text

39. Blankenship JW, Varfolomeev E, Goncharov T, et al:: Ubiquitin binding modulates IAP antagonist-stimulated proteasomal degradation of c-IAP1 and c-IAP2(1). Biochem J. 2009; 417(1): 149-60. PubMed Abstract | Publisher Full Text

40. F MacFarlane M, Merrison W, Bratton SB, et al:: Proteasome-mediated degradation of Smac during apoptosis: XIAP promotes Smac ubiquitination in vitro. J Biol Chem. 2002; 277(39): 36611-6. PubMed Abstract | Publisher Full Text | F1000 Recommendation

41. F Suzuki Y, Nakabayashi $Y$, Takahashi R: Ubiquitin-protein ligase activity of $\mathrm{X}$-linked inhibitor of apoptosis protein promotes proteasomal degradation of caspase-3 and enhances its anti-apoptotic effect in Fas-induced cell death Proc Natl Acad Sci U S A. 2001; 98(15): 8662-7. PubMed Abstract | Publisher Full Text | Free Full Text | F1000 Recommendation

42. Shin H, Renatus M, Eckelman BP, et al.: The BIR domain of IAP-like protein 2 is conformationally unstable: implications for caspase inhibition. Biochem J. 2005; 385(Pt 1): 1-10.

PubMed Abstract | Publisher Full Text | Free Full Text

43. Qu XB, Goldberg AL: The membrane-associated inhibitor of apoptosis protein, 
BRUCE/Apollon, antagonizes both the precursor and mature forms of Smac and caspase-9. J Biol Chem. 2005; 280(1): 174-82.

PubMed Abstract | Publisher Full Text

44. Qiu XB, Markant SL, Yuan J, et al:: Nrdp1-mediated degradation of the gigantic IAP, BRUCE, is a novel pathway for triggering apoptosis. EMBO J. 2004; 23(4) $800-10$

PubMed Abstract | Publisher Full Text | Free Full Text

45. Martin SJ: An Apollon vista of death and destruction. Nat Cell Biol. 2004; 6(9): 804-6.

PubMed Abstract | Publisher Full Text

46. Sokka A, Mudo G, Aaltonen J, et al: Bruce/apollon promotes hippocampal neuron survival and is downregulated by kainic acid. Biochem Biophys Res Commun. 2005; 338(2): 729-35.

PubMed Abstract | Publisher Full Text

47. Hao Y, Sekine K, Kawabata A, et al.: Apollon ubiquitinates SMAC and caspase9, and has an essential cytoprotection function. Nat Cell Biol. 2004; 6(9): 849-60.

PubMed Abstract | Publisher Full Tex

48. Ren J, Shi M, Liu R, et al.: The Birc6 (Bruce) gene regulates p53 and the mitochondrial pathway of apoptosis and is essential for mouse embryonic development. Proc Natl Acad Sci U S A. 2005; 102(3): 565-70. PubMed Abstract | Publisher Full Text | Free Full Text

49. Koonin EV, Aravind L: The NACHT family - a new group of predicted NTPases implicated in apoptosis and MHC transcription activation. Trends Biochem Sci. 2000; 25(5): 223-4

PubMed Abstract | Publisher Full Text

50. Mercer EA, Korhonen L, Skoglösa Y, et al.: NAIP interacts with hippocalcin and protects neurons against calcium-induced cell death through caspase3-dependent and -independent pathways. EMBO J. 2000; 19(14): 3597-607. PubMed Abstract | Publisher Full Text | Free Full Text

51. Gotz R, Karch C, Digby MR, et al.: The neuronal apoptosis inhibitory protein suppresses neuronal differentiation and apoptosis in PC12 cells. Hum Mol Genet. 2000; 9(17): 2479-89.

PubMed Abstract | Publisher Full Text

52. F Kofoed EM, Vance RE: Innate immune recognition of bacterial ligands by NAIPs determines inflammasome specificity. Nature. 2011; 477(7366): 592-5. PubMed Abstract | Publisher Full Text | Free Full Text | F1000 Recommendation

53. F Tenthorey JL, Kofoed EM, Daugherty MD, et al.: Molecular basis for specific recognition of bacterial ligands by NAIP/NLRC4 inflammasomes. Mol Cell. 2014; 54(1): 17-29.

PubMed Abstract | Publisher Full Text | Free Full Text | F1000 Recommendation

54. F Rauch I, Tenthorey JL, Nichols RD, et al:: NAIP proteins are required fo cytosolic detection of specific bacterial ligands in vivo. J Exp Med. 2016; 213(5): 657-65.

PubMed Abstract | Publisher Full Text | Free Full Text | F1000 Recommendation

55. F Lopez J, John SW, Tenev T, et al:: CARD-mediated autoinhibition of cIAP1's E3 ligase activity suppresses cell proliferation and migration. Mol Cell. 2011 42(5): 569-83.

PubMed Abstract | Publisher Full Text | F1000 Recommendation

56. F Mahoney DJ, Cheung HH, Mrad RL, et al:: Both cIAP1 and cIAP2 regulate TNFalpha-mediated NF-kappaB activation. Proc Natl Acad Sci U S A. 2008; 105(33): 11778-83.

PubMed Abstract | Publisher Full Text | Free Full Text | F1000 Recommendation

57. Varfolomeev E, Goncharov T, Fedorova AV, et al:: c-IAP1 and c-IAP2 are critica mediators of tumor necrosis factor alpha (TNFalpha)-induced NF-kappaB activation. J Biol Chem. 2008; 283(36): 24295-9.

PubMed Abstract | Publisher Full Text | Free Full Text

58. Mace PD, Smits $C$, Vaux DL, et al.: Asymmetric recruitment of clAPs by TRAF2 J Mol Biol. 2010; 400(1): 8-15.

PubMed Abstract | Publisher Full Text

59. Samuel T, Welsh K, Lober T, et al.: Distinct BIR domains of cIAP1 mediate binding to and ubiquitination of tumor necrosis factor receptor-associated factor 2 and second mitochondrial activator of caspases. J Biol Chem. 2006; 281(2): 1080-90.

PubMed Abstract | Publisher Full Text

60. Ashkenazi A, Dixit VM: Death receptors: signaling and modulation. Science. 1998; 281(5381): 1305-8.

PubMed Abstract | Publisher Full Text

61. Locksley RM, Killeen N, Lenardo MJ: The TNF and TNF receptor superfamilies: integrating mammalian biology. Cell. 2001; 104(4): 487-501. PubMed Abstract | Publisher Full Text

62. Nagata S: Apoptosis by death factor. Cell. 1997; 88(3): 355-65. PubMed Abstract | Publisher Full Text

63. Sessler T, Healy S, Samali A, et al: Structural determinants of DISC function new insights into death receptor-mediated apoptosis signalling

Pharmacol Ther. 2013; 140(2): 186-99.

PubMed Abstract | Publisher Full Text

64. Finlay D, Vamos M, González-López M, et al:: Small-molecule IAP antagonists sensitize cancer cells to TRAIL-induced apoptosis: roles of XIAP and cIAPs. Mol Cancer Ther. 2014; 13(1): 5-15.

PubMed Abstract | Publisher Full Text | Free Full Text
65. Lee S, Challa-Malladi M, Bratton SB, et al:: Nuclear factor-кB-inducing kinase (NIK) contains an amino-terminal inhibitor of apoptosis (IAP)-binding motif (IBM) that potentiates NIK degradation by cellular IAP1 (c-IAP1). J Biol Chem. 2014; 289(44): 30680-9.

PubMed Abstract | Publisher Full Text | Free Full Text

66. F Varfolomeev E, Blankenship JW, Wayson SM, et al.: IAP antagonists induce autoubiquitination of C-IAPs, NF-kappaB activation, and TNFalpha-dependent apoptosis. Cell. 2007; 131(4): 669-81.

PubMed Abstract | Publisher Full Text | F1000 Recommendation

67. F Harper N, Hughes M, MacFarlane M, et al.: Fas-associated death domain protein and caspase- 8 are not recruited to the tumor necrosis factor recepto 1 signaling complex during tumor necrosis factor-induced apoptosis. $J$ Biol Chem. 2003; 278(28): 25534-41.

PubMed Abstract | Publisher Full Text | F1000 Recommendation

68. F Micheau O, Tschopp J: Induction of TNF receptor I-mediated apoptosis via two sequential signaling complexes. Cell. 2003; 114(2): 181-90. PubMed Abstract | Publisher Full Text | F1000 Recommendation

69. Vucic D, Dixit VM, Wertz IE: Ubiquitylation in apoptosis: a post-translational modification at the edge of life and death. Nat Rev Mol Cell Biol. 2011; 12(7): 439-52.

PubMed Abstract | Publisher Full Text

70. Bertrand MJ, Vandenabeele P: The Ripoptosome: death decision in the cytosol. Mol Cell. 2011; 43(3): 323-5.

PubMed Abstract | Publisher Full Text

71. Imre G, Larisch S, Rajalingam K: Ripoptosome: a novel IAP-regulated cell deathsignalling platform. J Mol Cell Biol. 2011; 3(6): 324-6.

PubMed Abstract | Publisher Full Text

72. Tenev T, Bianchi K, Darding M, et al.: The Ripoptosome, a signaling platform that assembles in response to genotoxic stress and loss of IAPs. Mol Cell. 2011; 43(3): 432-48.

PubMed Abstract | Publisher Full Text

73. Zhou Z, Han V, Han J: New components of the necroptotic pathway. Protein Cell. 2012; 3(11): 811-7.

PubMed Abstract | Publisher Full Text | Free Full Text

74. Chen W, Zhou Z, Li L, et al.: Diverse sequence determinants control human and mouse receptor interacting protein 3 (RIP3) and mixed lineage kinase domainlike (MLKL) interaction in necroptotic signaling. J Biol Chem. 2013; 288(23): 16247-61.

PubMed Abstract | Publisher Full Text | Free Full Text

75. F Rodriguez DA, Weinlich R, Brown S, et al:: Characterization of RIPK3mediated phosphorylation of the activation loop of MLKL during necroptosis. Cell Death Differ. 2016; 23(1): 76-88.

PubMed Abstract | Publisher Full Text | Free Full Text | F1000 Recommendation

76. F Sun L, Wang $\mathrm{H}$, Wang $\mathrm{Z}$, et al.: Mixed lineage kinase domain-like protein mediates necrosis signaling downstream of RIP3 kinase. Cell. 2012; 148(1-2): 213-27.

PublMed Abstract | Publisher Full Text | F1000 Recommendation

77. F Cai Z, Jitkaew S, Zhao J, et al.: Plasma membrane translocation of trimerized MLKL protein is required for TNF-induced necroptosis. Nat Cell Biol. 2014; 16(1): 55-65.

PubMed Abstract | Publisher Full Text | F1000 Recommendation

78. F Chen X, Li W, Ren J, et al:: Translocation of mixed lineage kinase domainlike protein to plasma membrane leads to necrotic cell death. Cell Res. 2014; 24(1): 105-21.

PubMed Abstract | Publisher Full Text | Free Full Text | F1000 Recommendation

79. Linkermann A, Kunzendorf U, Krautwald S: Phosphorylated MLKL causes plasma membrane rupture. Mol Cell Oncol. 2014; 1(1): e29915. PubMed Abstract | Publisher Full Text | Free Full Text

80. Dickens LS, Powley IR, Hughes MA, et al.: The 'complexities' of life and death: death receptor signalling platforms. Exp Cell Res. 2012; 318(11): 1269-77. PubMed Abstract | Publisher Full Text

81. Feoktistova $M$, Geserick $P$, Panayotova-Dimitrova $\mathrm{D}$, et al:: Pick your poison: the Ripoptosome, a cell death platform regulating apoptosis and necroptosis. Cell Cycle. 2012; 11(3): 460-7. PubMed Abstract | Publisher Full Tex

82. Riedl SJ, Renatus M, Schwarzenbacher R, et al:: Structural basis for the inhibition of caspase-3 by XIAP. Cell. 2001; 104(5): 791-800. PubMed Abstract | Publisher Full Text

83. Huang Y, Park YC, Rich RL, et al:: Structural basis of caspase inhibition by XIAP: differential roles of the linker versus the BIR domain. Cell. 2001; 104(5): $781-90$.

PubMed Abstract | Publisher Full Text

84. Takahashi R, Deveraux Q, Tamm I, et al.: A single BIR domain of XIAP sufficient for inhibiting caspases. J Biol Chem. 1998; 273(14): 7787-90. PubMed Abstract

85. Srinivasula SM, Hegde R, Saleh A, et al: A conserved XIAP-interaction motif in caspase- 9 and Smac/DIABLO regulates caspase activity and apoptosis. Nature. 2001; 410(6824): 112-6.

PubMed Abstract | Publisher Full Text

86. Bratton SB, Walker G, Srinivasula SM, et al: Recruitment, activation and 
retention of caspases- 9 and $\mathbf{- 3}$ by Apaf-1 apoptosome and associated XIAP complexes. EMBO J. 2001; 20(5): 998-1009.

PubMed Abstract | Publisher Full Text | Free Full Text

87. Datta R, Oki E, Endo K, et al:: XIAP regulates DNA damage-induced apoptosis downstream of caspase-9 cleavage. J Biol Chem. 2000; 275(41): 31733-8. PubMed Abstract | Publisher Full Text

88. F Du C, Fang M, Li Y, et al.: Smac, a mitochondrial protein that promotes cytochrome c-dependent caspase activation by eliminating IAP inhibition. Cell. 2000; 102(1): 33-42.

PubMed Abstract | Publisher Full Text | F1000 Recommendation

89. Liu Z, Sun C, Olejniczak ET, et al:: Structural basis for binding of Smac/DIABLO to the XIAP BIR3 domain. Nature. 2000; 408(6815): 1004-8. PubMed Abstract | Publisher Full Text

90. Wu G, Chai J, Suber TL, et al:: Structural basis of IAP recognition by Smac/ DIABLO. Nature. 2000; 408(6815): 1008-12. PubMed Abstract | Publisher Full Text

91. Ekert PG, Silke J, Hawkins CJ, et al.: DIABLO promotes apoptosis by removing MIHA/XIAP from processed caspase 9. J Cell Biol. 2001; 152(3): 483-90. PubMed Abstract | Publisher Full Text | Free Full Text

92. Hanahan D, Weinberg RA: The hallmarks of cancer. Cell. 2000; 100(1): 57-70. PubMed Abstract | Publisher Full Text

93. Levine B, Kroemer G: Autophagy in the pathogenesis of disease. Cell. 2008; 132(1): 27-42. PubMed Abstract | Publisher Full Text | Free Full Text

94. F Hanahan D, Weinberg RA: Hallmarks of cancer: the next generation. Cell. 2011; 144(5): 646-74

PubMed Abstract | Publisher Full Text | F1000 Recommendation

95. Ouyang L, Shi Z, Zhao S, et al.: Programmed cell death pathways in cancer: review of apoptosis, autophagy and programmed necrosis. Cell Prolif. 2012; 45(6): 487-98.

PubMed Abstract | Publisher Full Text

96. Reed JC: Dysregulation of apoptosis in cancer. J Clin Oncol. 1999; 17(9): 2941-53. PubMed Abstract | Publisher Full Text

97. Reed JC: Mechanisms of apoptosis avoidance in cancer. Curr Opin Oncol. 1999; 11(1): $68-75$

PubMed Abstract | Publisher Full Text

98. Liston P, Fong WG, Korneluk RG: The inhibitors of apoptosis: there is more to life than Bcl2. Oncogene. 2003; 22(53): 8568-80.

PubMed Abstract | Publisher Full Tex

99. Schimmer AD: Inhibitor of apoptosis proteins: translating basic knowledge into clinical practice. Cancer Res. 2004; 64(20): 7183-90. PubMed Abstract | Publisher Full Text

100. Nachmias B, Ashhab $Y$, Ben-Yehuda D: The inhibitor of apoptosis protein family (IAPs): an emerging therapeutic target in cancer. Semin Cancer Biol. 2004; 14(4): 231-43. PubMed Abstract | Publisher Full Text

101. Fan TJ, Han LH, Cong RS, et al.: Caspase family proteases and apoptosis. Acta Biochim Biophys Sin (Shanghai). 2005; 37(11): 719-27. PubMed Abstract | Publisher Full Text

102. Hunter AM, LaCasse EC, Korneluk RG: The inhibitors of apoptosis (IAPs) as cancer targets. Apoptosis. 2007; 12(9): 1543-68. PubMed Abstract | Publisher Full Text

103. Reubold TF, Eschenburg S: A molecular view on signal transduction by the apoptosome. Cell Signal. 2012; 24(7): 1420-5. PubMed Abstract | Publisher Full Text

104. Deveraux QL, Reed JC: IAP family proteins--suppressors of apoptosis. Genes Dev. 1999; 13(3): 239-52. PubMed Abstract

105. F Hong X, Lei L, Glas R: Tumors acquire inhibitor of apoptosis protein (IAP)-mediated apoptosis resistance through altered specificity of cytosolic proteolysis. J Exp Med. 2003; 197(12): 1731-43.

PubMed Abstract | Publisher Full Text | Free Full Text | F1000 Recommendation

106. Holcik M, Yeh C, Korneluk RG, et al.: Translational upregulation of X-linked inhibitor of apoptosis (XIAP) increases resistance to radiation induced cell death. Oncogene. 2000; 19(36): 4174-7. PubMed Abstract | Publisher Full Text

107. Nemoto T, Kitagawa M, Hasegawa M, et al.: Expression of IAP family proteins in esophageal cancer. Exp Mol Pathol. 2004; 76(3): 253-9. PubMed Abstract | Publisher Full Text

108. Choi J, Hwang YK, Choi YJ, et al.: Neuronal apoptosis inhibitory protein is overexpressed in patients with unfavorable prognostic factors in breast cancer. J Korean Med Sci. 2007; 22 Suppl: S17-23. PubMed Abstract | Publisher Full Text | Free Full Text

109. Chiu $\mathrm{HH}$, Yong TM, Wang J, et al.: Induction of neuronal apoptosis inhibitory protein expression in response to androgen deprivation in prostate cancer. Cancer Lett. 2010; 292(2): 176-85. PubMed Abstract | Publisher Full Text | Free Full Text

110. F Harvey H, Piskareva O, Creevey L, et al.: Modulation of chemotherapeutic drug resistance in neuroblastoma SK-N-AS cells by the neural apoptosis inhibitory protein and miR-520f. Int J Cancer. 2015; 136(7): 1579-88. PubMed Abstract | Publisher Full Text | F1000 Recommendation
111. Fulda S, Vucic D: Targeting IAP proteins for therapeutic intervention in cance Nat Rev Drug Discov. 2012; 11(2): 109-24.

PubMed Abstract | Publisher Full Text

112. Fulda S: Promises and Challenges of Smac Mimetics as Cancer Therapeutics. Clin Cancer Res. 2015; 21(22): 5030-6. PubMed Abstract | Publisher Full Tex

113. Zarnegar BJ, Wang Y, Mahoney DJ, et al:: Noncanonical NF-kappaB activation requires coordinated assembly of a regulatory complex of the adaptors cIAP1, cIAP2, TRAF2 and TRAF3 and the kinase NIK. Nat Immunol. 2008; 9(12): 1371-8. PublMed Abstract | Publisher Full Text | Free Full Text

114. Ma O, Cai W, Zender L, et al:: MMP13, Birc2 (cIAP1), and Birc3 (cIAP2), amplified on chromosome 9, collaborate with p53 deficiency in mouse osteosarcoma progression. Cancer Res. 2009; 69(6): 2559-67. PubMed Abstract | Publisher Full Text | Free Full Text

115. Zender L, Spector MS, Xue W, et al.: Identification and validation of oncogenes in liver cancer using an integrative oncogenomic approach. Cell. 2006; 125(7): $1253-67$.

PubMed Abstract | Publisher Full Text | Free Full Text

116. F Bertrand MJ, Milutinovic S, Dickson KM, et al.: cIAP1 and cIAP2 facilitate cancer cell survival by functioning as E3 ligases that promote RIP1 ubiquitination. Mol Cell. 2008; 30(6): 689-700. PubMed Abstract | Publisher Full Text | F1000 Recommendation

117. Kenneth NS, Duckett CS: IAP proteins: regulators of cell migration and development. Curr Opin Cell Biol. 2012; 24(6): 871-5. PubMed Abstract | Publisher Full Text

118. Oberoi-Khanuja TK, Murali A, Rajalingam K: IAPs on the move: role of inhibitors of apoptosis proteins in cell migration. Cell Death Dis. 2013; 4: e784. PubMed Abstract | Publisher Full Text | Free Full Text

119. Kingeter LM, Schaefer BC: Malt1 and cIAP2-Malt1 as effectors of NF-kappaB activation: kissing cousins or distant relatives? Cell Signal. 2010; 22(1): 9-22. PubMed Abstract | Publisher Full Text | Free Full Text

120. Tamm I, Kornblau SM, Segall $\mathrm{H}$, et al:: Expression and prognostic significance of IAP-family genes in human cancers and myeloid leukemias. Clin Cancer Res. 2000; 6(5): 1796-803. PubMed Abstract

121. Tamm I, Richter S, Oltersdorf D, et al.: High expression levels of $\mathbf{x}$-linked inhibitor of apoptosis protein and survivin correlate with poor overall survival in childhood de novo acute myeloid leukemia. Clin Cancer Res. 2004; 10(11): 3737-44.

PubMed Abstract | Publisher Full Text

122. Mizutani $\mathrm{Y}$, Nakanishi $\mathrm{H}$, Li YN, et al:: Overexpression of XIAP expression in renal cell carcinoma predicts a worse prognosis. Int J Oncol. 2007; 30(4): 919-25.

PubMed Abstract | Publisher Full Text

123. Ramp U, Krieg $\mathrm{T}$, Caliskan $\mathrm{E}$, et al.: XIAP expression is an independent prognostic marker in clear-cell renal carcinomas. Hum Pathol. 2004; 35(8) $1022-8$.

PubMed Abstract | Publisher Full Text

124. Nakagawa $\mathrm{Y}$, Abe $\mathrm{S}$, Kurata M, et al.: IAP family protein expression correlates with poor outcome of multiple myeloma patients in association with chemotherapy-induced overexpression of multidrug resistance genes. Am J Hematol. 2006; 81(11): 824-31. PubMed Abstract | Publisher Full Text

125. Li M, Song T, Yin ZF, et al:: XIAP as a prognostic marker of early recurrence of nonmuscular invasive bladder cancer. Chin Med J (Engl). 2007; 120(6): 469-73. PubMed Abstract

126. Dean EJ, Ranson M, Blackhall F, et al:: X-linked inhibitor of apoptosis protein as a therapeutic target. Expert Opin Ther Targets. 2007; 11(11): 1459-71. PubMed Abstract | Publisher Full Text

127. Altieri DC, Edgington TS: Identification of effector cell protease receptor-1. A leukocyte-distributed receptor for the serine protease factor Xa. J Immunol. 1990; 145(1): 246-53. PubMed Abstract

128. Altieri DC: Survivin, cancer networks and pathway-directed drug discovery. Nat Rev Cancer. 2008; 8(1): 61-70. PubMed Abstract | Publisher Full Text

129. Kami K, Doi $R$, Koizumi $M$, et al.: Survivin expression is a prognostic marker in pancreatic cancer patients. Surgery. 2004; 136(2): 443-8. PubMed Abstract | Publisher Full Text

130. Sugahara $\mathrm{K}$, Uemura $\mathrm{A}$, Harasawa $\mathrm{H}$, et al.: Clinical relevance of survivin as a biomarker in neoplasms, especially in adult T-cell leukemias and acute leukemias. Int $J$ Hematol. 2004; 80(1): 52-8. PubMed Abstract | Publisher Full Text

131. Mega S, Miyamoto M, Li L, et al:: Immunohistochemical analysis of nuclear survivin expression in esophageal squamous cell carcinoma. Dis Esophagus. 2006; 19(5): 355-9. PubMed Abstract | Publisher Full Text

132. Gritsko T, Williams A, Turkson J, et al:: Persistent activation of stat3 signaling induces survivin gene expression and confers resistance to apoptosis in human breast cancer cells. Clin Cancer Res. 2006; 12(1): 11-9. PubMed Abstract | Publisher Full Text

133. Kaneko R, Tsuji N, Asanuma K, et al:: Survivin down-regulation plays a crucial 
role in 3-hydroxy-3-methylglutaryl coenzyme A reductase inhibitor-induced apoptosis in cancer. J Biol Chem. 2007; 282(27): 19273-81.

PubMed Abstract | Publisher Full Text

134. Stauber RH, Mann W, Knauer SK: Nuclear and cytoplasmic survivin: molecular mechanism, prognostic, and therapeutic potential. Cancer Res. 2007; 67(13): 5999-6002.

PubMed Abstract | Publisher Full Text

135. Waligórska-Stachura J, Jankowska A, Wasko R, et al:: Survivin--prognostic tumor biomarker in human neoplasms--review. Ginekol Pol. 2012; 83(7): 537-40. PubMed Abstract

136. F Jaiswal PK, Goel A, Mittal RD: Survivin: A molecular biomarker in cancer. Indian J Med Res. 2015; 141(4): 389-97. PubMed Abstract | Publisher Full Text | Free Full Text | F1000 Recommendation

137. Altieri DC: Survivin - The inconvenient IAP. Semin Cell Dev Biol. 2015; 39: 91-6. PubMed Abstract | Publisher Full Text | Free Full Text

138. F Soleimanpour E, Babaei E: Survivin as a Potential Target for Cancer Therapy. Asian Pac J Cancer Prev. 2015; 16(15): 6187-91. PubMed Abstract | Publisher Full Text | F1000 Recommendation

139. Tamm I, Wang Y, Sausville E, et al.: IAP-family protein survivin inhibits caspase activity and apoptosis induced by Fas (CD95), Bax, caspases, and anticancer drugs. Cancer Res. 1998; 58(23): 5315-20. PubMed Abstract

140. Kobayashi K, Hatano M, Otaki M, et al.: Expression of a murine homologue of the inhibitor of apoptosis protein is related to cell proliferation. Proc Natl Acad SciU S A. 1999; 96(4): 1457-62. PubMed Abstract | Publisher Full Text | Free Full Text

141. Mahotka C, Wenzel M, Springer E, et al.: Survivin-deltaEx3 and survivin-2B: two novel splice variants of the apoptosis inhibitor survivin with different antiapoptotic properties. Cancer Res. 1999; 59(24): 6097-102. PubMed Abstract

142. Dohi T, Okada K, Xia F, et al:: An IAP-IAP complex inhibits apoptosis. J Biol Chem. 2004; 279(33): 34087-90.

PubMed Abstract | Publisher Full Text

143. Speliotes EK, Uren A, Vaux D, et al:: The survivin-like C. elegans BIR-1 protein acts with the Aurora-like kinase AIR-2 to affect chromosomes and the spindle midzone. Mol Cell. 2000; 6(2): 211-23. PubMed Abstract | Publisher Full Text

144. Cheung $\mathrm{CH}$, Huang $\mathrm{CC}$, Tsai FY, et al:: Survivin - biology and potential as a therapeutic target in oncology. Onco Targets Ther. 2013; 6: 1453-62. PubMed Abstract | Publisher Full Text | Free Full Text

145. Coumar MS, Tsai FY, Kanwar JR, et al.: Treat cancers by targeting survivin: just a dream or future reality? Cancer Treat Rev. 2013; 39(7): 802-11. PubMed Abstract | Publisher Full Text

146. F Garg H, Suri P, Gupta JC, et al.: Survivin: a unique target for tumor therapy. Cancer Cell Int. 2016; 16: 49.

PubMed Abstract | Publisher Full Text | Free Full Text | F1000 Recommendation

147. F Chen X, Duan N, Zhang C, et al.: Survivin and Tumorigenesis: Molecular Mechanisms and Therapeutic Strategies. J Cancer. 2016; 7(3): 314-23. PubMed Abstract | Publisher Full Text | Free Full Text | F1000 Recommendation

148. Han Z, Lee S, Je S, et al:: Survivin silencing and TRAIL expression using oncolytic adenovirus increase anti-tumorigenic activity in gemcitabineresistant pancreatic cancer cells. Apoptosis. 2016; 21(3): 351-64. PubMed Abstract | Publisher Full Text

149. Bi $Y$, Zhang $Y$, Cui $C$, et al.: Gene-silencing effects of anti-survivin siRNA delivered by RGDV-functionalized nanodiamond carrier in the breas carcinoma cell line MCF-7. Int J Nanomedicine. 2016; 11: 5771-87. PubMed Abstract | Publisher Full Text | Free Full Text

150. Ling $X$, Cao $S$, Cheng $Q$, et al.: A novel small molecule FL118 that selectively inhibits survivin, Mcl-1, XIAP and cIAP2 in a p53-independent manner, shows superior antitumor activity. PLOS One. 2012; 7(9): e45571. PubMed Abstract | Publisher Full Text | Free Full Text

151. Falkenhorst J, Grunewald S, Mühlenberg T, et al:: Inhibitor of Apoptosis Protein (IAPs) are commonly dysregulated in GIST and can be pharmacologically targeted to enhance the pro-apoptotic activity of imatinib. Oncotarget. 2016 7(27): 41390-403.

PubMed Abstract | Publisher Full Text | Free Full Text

152. Gyurászová K, Mikeš J, Halaburková $\mathrm{A}$, et al: YM155, a small molecule inhibitor of survivin expression, sensitizes cancer cells to hypericin-mediated photodynamic therapy. Photochem Photobiol Sci. 2016; 15(6): 812-21. PubMed Abstract | Publisher Full Text

153. Groner B, Weiss A: Targeting survivin in cancer: novel drug development approaches. BioDrugs. 2014; 28(1): 27-39. PubMed Abstract | Publisher Full Text | Free Full Text

154. Xiao M, Li W: Recent Advances on Small-Molecule Survivin Inhibitors. Curr Med Chem. 2015; 22(9): 1136-1146. PubMed Abstract | Publisher Full Text | Free Full Text

155. Qi J, Dong Z, Liu J, et al.: Effective Targeting of the Survivin Dimerization Interface with Small-Molecule Inhibitors. Cancer Res. 2016; 76(2): 453-62. PubMed Abstract | Publisher Full Text

156. Sung KW, Choi J, Hwang YK, et al.: Overexpression of Apollon, an antiapoptotic protein, is associated with poor prognosis in childhood de novo acute myeloid leukemia. Clin Cancer Res. 2007; 13(17): 5109-14

PubMed Abstract | Publisher Full Text

157. Ismail EA, Mahmoud HM, Tawfik LM, et al:: BIRC6/Apollon gene expression in childhood acute leukemia: impact on therapeutic response and prognosis. Eur $J$ Haematol. 2012; 88(2): 118-27.

PubMed Abstract | Publisher Full Text

158. Lopergolo A, Pennati M, Gandellini P, et al:: Apollon gene silencing induces apoptosis in breast cancer cells through $\mathrm{p} 53$ stabilisation and caspase- 3 activation. Br J Cancer. 2009; 100(5): 739-46.

PubMed Abstract | Publisher Full Text | Free Full Text

159. Lamers F, Schild L, Koster J, et al:: Identification of BIRC6 as a novel intervention target for neuroblastoma therapy. BMC Cancer. 2012; 12: 285. PubMed Abstract | Publisher Full Text | Free Full Text

160. Low CG, Luk IS, Lin D, et al.: BIRC6 protein, an inhibitor of apoptosis: role in survival of human prostate cancer cells. PLoS One. 2013; 8(2): e55837. PubMed Abstract | Publisher Full Text | Free Full Text

161. Luk SU, Xue H, Cheng H, et al.: The BIRC6 gene as a novel target for therapy of prostate cancer: dual targeting of inhibitors of apoptosis. Oncotarget. 2014 5(16): 6896-908.

PubMed Abstract | Publisher Full Text | Free Full Text

162. F Luk IS, Shrestha R, Xue H, et al.: BIRC6 Targeting as Potential Therapy for Advanced, Enzalutamide-Resistant Prostate Cancer. Clin Cancer Res. 2017; 23(6): 1542-1551.

PubMed Abstract | Publisher Full Text | F1000 Recommendation

163. Dong $X$, Lin D, Low C, et al.: Elevated expression of BIRC6 protein in non-smallcell lung cancers is associated with cancer recurrence and chemoresistance. J Thorac Oncol. 2013; 8(2): 161-70. PubMed Abstract | Publisher Full Text

164. F Wang L, Chen YJ, Hou J, et al.: Expression and clinical significance of BIRC6 in human epithelial ovarian cancer. Tumour Biol. 2014; 35(5): 4891-6. PubMled Abstract | Publisher Full Text | F1000 Recommendation

165. F Hu T, Weng S, Tang W, et al:: Overexpression of BIRC6 Is a Predictor of Prognosis for Colorectal Cancer. PLOS One. 2015; 10(5): e0125281. PubMed Abstract | Publisher Full Text | Free Full Text | F1000 Recommendation

166. F Tang W, Xue R, Weng S, et al.: BIRC6 promotes hepatocellular carcinogenesis: interaction of BIRC6 with p53 facilitating p53 degradation. Int J Cancer. 2015; 136(6): E475-87.

PubMed Abstract | Publisher Full Text | F1000 Recommendation

167. F Li R, Chen BL, Zhou YW, et al.: Expression and clinical significance of Apollon in esophageal squamous cell carcinoma. Mol Med Rep. 2016; 14(3): $1933-40$.

PubMed Abstract | Publisher Full Text | Free Full Text | F1000 Recommendation

168. F Milani S, Bandehpour M, Sharifi Z, et al:: Suppressive Effect of Constructed shRNAs against Apollon Induces Apoptosis and Growth Inhibition in the HeLa Cell Line. Iran Biomed J. 2016; 20(3): 145-51.

PubMed Abstract | Publisher Full Text | Free Full Text | F1000 Recommendation

169. Varfolomeev E, Moradi E, Dynek JN, et al:: Characterization of ML-IAP protein stability and physiological role in vivo. Biochem J. 2012; 447(3): 427-36. PubMed Abstract | Publisher Full Text

170. Ma L, Huang Y, Song Z, et al.: Livin promotes Smac/DIABLO degradation by ubiquitin-proteasome pathway. Cell Death Differ. 2006; 13(12): 2079-88. PubMed Abstract | Publisher Full Text

171. Hariu $\mathrm{H}$, Hirohashi $\mathrm{Y}$, Torigoe $\mathrm{T}$, et al: : Aberrant expression and potency as a cancer immunotherapy target of inhibitor of apoptosis protein family, Livin/ ML-IAP in lung cancer. Clin Cancer Res. 2005; 11(3): 1000-9. PubMed Abstract

172. Tanabe $\mathrm{H}$, Yagihashi $\mathrm{A}$, Tsuji $\mathrm{N}$, et al:: Expression of survivin mRNA and livin mRNA in non-small-cell lung cancer. Lung Cancer. 2004; 46(3): 299-304. PubMled Abstract | Publisher Full Text

173. Crnković-Mertens I, Muley T, Meister M, et al:: The anti-apoptotic livin gene is an important determinant for the apoptotic resistance of non-small cell lung cancer cells. Lung Cancer. 2006; 54(2): 135-42. PubMed Abstract | Publisher Full Text

174. Dasgupta A, Alvarado CS, Xu Z, et al:: Expression and functional role of inhibitor-of-apoptosis protein livin (BIRC7) in neuroblastoma. Biochem Biophys Res Commun. 2010; 400(1): 53-9. PubMed Abstract | Publisher Full Text

175. El-Mesallamy HO, Hegab HM, Kamal AM: Expression of inhibitor of apoptosis protein (IAP) livin/BIRC7 in acute leukemia in adults: correlation with prognostic factors and outcome. Leuk Res. 2011; 35(12): 1616-22. PubMed Abstract | Publisher Full Text

176. Grzybowska-Izydorczyk O, Cebula B, Robak T, et al.: Expression and prognostic significance of the inhibitor of apoptosis protein (IAP) family and its antagonists in chronic lymphocytic leukaemia. Eur J Cancer. 2010; 46(4): 800-10.

PubMed Abstract | Publisher Full Text

177. Kim DK, Alvarado CS, Abramowsky CR, et al.: Expression of inhibitor-ofapoptosis protein (IAP) livin by neuroblastoma cells: correlation with prognostic factors and outcome. Pediatr Dev Pathol. 2005; 8(4): 621-9. PubMed Abstract | Publisher Full Text 
178. Xi RC, Biao WS, Gang ZZ: Significant elevation of survivin and livin expression in human colorectal cancer: inverse correlation between expression and overall survival. Onkologie. 2011; 34(8-9): 428-32. PubMed Abstract | Publisher Full Text

179. Zhou J, Yuen NK, Zhan Q, et al.: Immunity to the melanoma inhibitor of apoptosis protein (ML-IAP; livin) in patients with malignant melanoma. Cancer Immunol Immunother. 2012; 61(5): 655-65. PubMed Abstract | Publisher Full Text | Free Full Text

180. Wagener N, Crnković-Mertens I, Vetter C, et al.: Expression of inhibitor of apoptosis protein Livin in renal cell carcinoma and non-tumorous adult kidney. Br J Cancer. 2007; 97(9): 1271-6.

PubMed Abstract | Publisher Full Text | Free Full Text

181. F Wang Z, Liu S, Ding K, et al.: Silencing Livin induces apoptotic and autophagic cell death, increasing chemotherapeutic sensitivity to cisplatin of renal carcinoma cells. Tumour Biol. 2016; 37(11): 15133-43. PubMed Abstract | Publisher Full Text | F1000 Recommendation

182. Li J, Chen $P, L i X Q$, et al.: Elevated levels of survivin and livin mRNA in bronchial aspirates as markers to support the diagnosis of lung cancer. Int J Cancer. 2013; 132(5): 1098-104. PubMed Abstract | Publisher Full Text

183. Yagihashi A, Asanuma K, Kobayashi D, et al.: Detection of autoantibodies to livin and survivin in Sera from lung cancer patients. Lung Cancer. 2005; 48(2): 217-21.

PubMed Abstract | Publisher Full Text

184. Gazzaniga P, Gradilone A, Giuliani L, et al.: Expression and prognostic significance of LIVIN, SURVIVIN and other apoptosis-related genes in the progression of superficial bladder cancer. Ann Oncol. 2003; 14(1): 85-90. PubMed Abstract | Publisher Full Text

185. Lazar I, Perlman R, Lotem M, et al.: The clinical effect of the inhibitor of apopotosis protein livin in melanoma. Oncology. 2012; 82(4): 197-204. PubMed Abstract | Publisher Full Text

186. Xi RC, Sheng YR, Chen WH, et al:: Expression of survivin and livin predicts early recurrence in non-muscle invasive bladder cancer. J Surg Oncol. 2013, 107(5): 550-4.

PubMed Abstract | Publisher Full Text

187. Yagihashi A, Ohmura T, Asanuma K, et al.: Detection of autoantibodies to survivin and livin in sera from patients with breast cancer. Clin Chim Acta. 2005; $362(1-2): 125-30$. PubMed Abstract | Publisher Full Text

188. Li G, Chang H, Zhai YP, et al.: Targeted silencing of inhibitors of apoptosis proteins with siRNAs: a potential anti-cancer strategy for hepatocellular carcinoma. Asian Pac J Cancer Prev. 2013; 14(9): 4943-52. PubMed Abstract | Publisher Full Text

189. Liu $\mathrm{H}$, Wang $\mathrm{S}$, Sun $\mathrm{H}$, et al.: Inhibition of tumorigenesis and invasion of hepatocellular carcinoma by siRNA-mediated silencing of the livin gene. $\mathrm{Mol}$ Med Rep. 2010; 3(6): 903-7. PubMed Abstract | Publisher Full Tex

190. Liu X, Wang A, Gao H, et al.: Expression and role of the inhibitor of apoptosis protein livin in chemotherapy sensitivity of ovarian carcinoma. Int J Oncol. 2012; 41(3): 1021-8. PubMed Abstract | Publisher Full Text

191. Sun JG, Liao RX, Zhang SX, et al.: Role of inhibitor of apoptosis protein Livin in radiation resistance in nonsmall cell lung cancer. Cancer Biother Radiopharm. 2011; 26(5): 585-92.

PubMed Abstract | Publisher Full Text

192. Yuan B, Ran B, Wang S, et al.: siRNA directed against Livin inhibits tumor growth and induces apoptosis in human glioma cells. J Neurooncol. 2012; 107(1): 81-7.

PubMed Abstract | Publisher Full Tex

193. Yang D, Song X, Zhang J, et al.: Therapeutic potential of siRNA-mediated combined knockdown of the IAP genes (Livin, XIAP, and Survivin) on human bladder cancer T24 cells. Acta Biochim Biophys Sin (Shanghai). 2010; 42(2): $137-44$

PubMed Abstract | Publisher Full Text

194. Yu L, Wang Z: Effects of Livin gene RNA interference on apoptosis of cervical cancer HeLa cells and enhanced sensitivity to cisplatin. J Huazhong Univ Sci Technolog Med Sci. 2009; 29(5): 625-30. PubMed Abstract | Publisher Full Text

195. Wang R, Lin F, Wang $X$, et al.: Silencing Livin gene expression to inhibit proliferation and enhance chemosensitivity in tumor cells. Cancer Gene Ther 2008; 15(6): 402-12.

PubMed Abstract | Publisher Full Text

196. Chen YS, Li HR, Miao Y, et al.: Local injection of lentivirus-delivered livinshRNA suppresses lung adenocarcinoma growth by inducing a G0/G1 phase cell cycle arrest. Int J Clin Exp Pathol. 2012; 5(8): 796-805. PubMed Abstract | Free Full Text

197. Oh BY, Lee RA, Kim KH: siRNA targeting Livin decreases tumor in a xenograft model for colon cancer. World J Gastroenterol. 2011; 17(20): 2563-71. PubMed Abstract | Publisher Full Text | Free Full Text

198. F Zhuang L, Shen LD, Li K, et al.: Inhibition of livin expression suppresses cell proliferation and enhances chemosensitivity to cisplatin in human lung adenocarcinoma cells. Mol Med Rep. 2015; 12(1): 547-52. PubMed Abstract | Publisher Full Text | F1000 Recommendation
199. Vamos M, Welsh K, Finlay D, et al:: Expedient synthesis of highly poten antagonists of inhibitor of apoptosis proteins (IAPs) with unique selectivity for ML-IAP. ACS Chem Biol. 2013; 8(4): 725-32.

PubMed Abstract | Publisher Full Text | Free Full Text

200. Xiang M, Zhou W, Gao D, et al.: Inhibitor of apoptosis protein-like protein-2 as a novel serological biomarker for breast cancer. Int J Mol Sci. 2012; 13(12): 16737-50.

PubMed Abstract | Publisher Full Text | Free Full Text

201. F Verhagen AM, Ekert PG, Pakusch M, et al:: Identification of DIABLO, a mammalian protein that promotes apoptosis by binding to and antagonizing IAP proteins. Cell. 2000; 102(1): 43-53.

PubMed Abstract | Publisher Full Text | F1000 Recommendation

202. Arkin MR, Tang Y, Wells JA: Small-molecule inhibitors of protein-protein interactions: progressing toward the reality. Chem Biol. 2014; 21(9): 1102-14. PubMed Abstract | Publisher Full Text | Free Full Text

203. Chai J, Du C, Wu JW, et al.: Structural and biochemical basis of apoptotic activation by Smac/DIABLO. Nature. 2000; 406(6798): 855-62. PubMed Abstract | Publisher Full Text

204. Guo F, Nimmanapalli R, Paranawithana S, et al: Ectopic overexpression of second mitochondria-derived activator of caspases (Smac/DIABLO) or cotreatment with $\mathrm{N}$-terminus of Smac/DIABLO peptide potentiates epothilone B derivative-(BMS 247550) and Apo-2L/TRAIL-induced apoptosis. Blood. 2002; 99(9): 3419-26.

PubMed Abstract | Publisher Full Text

205. Arnt CR, Chiorean MV, Heldebrant MP, et al:: Synthetic Smac/DIABLO peptides enhance the effects of chemotherapeutic agents by binding XIAP and cIAP1 in situ. J Biol Chem. 2002; 277(46): 44236-43.

PubMed Abstract | Publisher Full Text

206. F Yang L, Mashima T, Sato S, et al.: Predominant suppression of apoptosome by inhibitor of apoptosis protein in non-small cell lung cancer $\mathrm{H} 460$ cells: therapeutic effect of a novel polyarginine-conjugated Smac peptide. Cancer Res. 2003; 63(4): 831-7.

PubMed Abstract | F1000 Recommendation

207. F Oost TK, Sun C, Armstrong RC, et al:: Discovery of potent antagonists of the antiapoptotic protein XIAP for the treatment of cancer. J Med Chem. 2004 47(18): 4417-26.

PubMed Abstract | Publisher Full Text | F1000 Recommendation

208. F Li L, Thomas RM, Suzuki H, et al:: A small molecule Smac mimic potentiates TRAIL- and TNFalpha-mediated cell death. Science. 2004; 305(5689): 1471-4. PubMed Abstract | Publisher Full Text | F1000 Recommendation

209. AstraZeneca: 2, 3-dihydro-1h-indene compounds and their use to treat cancer. Reference Source

210. Bourguet CB, Boulay PL, Claing A, et al:: Design and synthesis of novel azapeptide activators of apoptosis mediated by caspase- 9 in cancer cells. Bioorg Med Chem Lett. 2014; 24(15): 3361-5. PubMed Abstract | Publisher Full Text

211. Bristol-Myers Squibb, Ensemble Therapeutics: Macrocyclic compounds for inhibition of inhibitors of apoptosis. WO2014074665A1, 2014 Reference Source

212. Genentech: Inhibitors of iap. WO2010017035A2, 2010 Reference Source

213. Genentech: Azaindole inhibitors of IAP. WO2010021934A2, 2010 Reference Source

214. Genentech: Inhibitors of IAP. US8835393B2, 2014 Reference Source

215. Hennessy EJ, Adam A, Aquila BM, et al:: Discovery of a novel class of dimeric Smac mimetics as potent IAP antagonists resulting in a clinical candidate for the treatment of cancer (AZD5582). J Med Chem. 2013; 56(24): 9897-919. PubMed Abstract | Publisher Full Text

216. Hanmi Holdings: Imidazopyrazinone derivatives with apoptosis inducing activity on cells. WO2011090317A2, 2011 Reference Source

217. Hanmi Holdings: Quinoline or quinazoline derivatives with apoptosis inducing activity on cells. WO2012030160A2, 2012. Reference Source

218. Boehringer Ingelheim International: 5-AlkynyI Pyridine. US20130225567A1, 2013. Reference Source

219. Boehringer Ingelheim International: New 6-alkynyl pyridine. WO2015025019A1, 2015. Reference Source

220. Boehringer Ingelheim International: New bis-amido pyridines. WO2015025018A1, 2015. Reference Source

221. Boehringer Ingelheim International: 6-alkynyl-pyridine derivatives. US20160039814A1, 2016. Reference Source

222. Lee SH, Lee JY, Jung CL, et al: A novel antagonist to the inhibitors of apoptosis (IAPs) potentiates cell death in EGFR-overexpressing non-small-cell lung cancer cells. Cell Death Dis. 2014; 5: e1477. PubMed Abstract | Publisher Full Text | Free Full Text

223. F Li N, Feng L, Han HQ, et al.: A novel Smac mimetic APG-1387 demonstrates 
potent antitumor activity in nasopharyngeal carcinoma cells by inducing apoptosis. Cancer Lett. 2016; 381(1): 14-22.

PubMed Abstract | Publisher Full Text | F1000 Recommendation

224. Manzoni L, Belvisi L, Bianchi A, et al:: Homo- and heterodimeric Smac mimetics/IAP inhibitors as in vivo-active pro-apoptotic agents. Part I: Synthesis. Bioorg Med Chem. 2012; 20(22): 6687-708

PubMed Abstract | Publisher Full Text

225. Novartis: Dimeric iap inhibitors. WO2011104266A1, 2011 Reference Source

226. Novartis: Dimeric iap inhibitors. WO2012080271A1, 2012 Reference Source

227. Peng Y, Sun H, Nikolovska-Coleska Z, et al:: Potent, orally bioavailable diazabicyclic small-molecule mimetics of second mitochondria-derived activator of caspases. J Med Chem. 2008; 51(24): 8158-62. PubMed Abstract | Publisher Full Text | Free Full Text

228. F Perez HL, Chaudhry C, Emanuel SL, et al.: Discovery of potent heterodimeric antagonists of inhibitor of apoptosis proteins (IAPs) with sustained antitumor activity. J Med Chem. 2015; 58(3): 1556-62. PubMed Abstract | Publisher Full Text | F1000 Recommendation

229. Allist Pharmaceuticals: Tetrapeptide analog, preparation method and application thereof. CN102050867A, 2011. Reference Source

230. Joyant Pharmaceuticals: Dimeric smac mimetics. WO2011059763A2, 2011. Reference Source

231. Roche: Substituted hetero-azepinones. WO2014023708A1, 2014. Reference Source

232. Roche: Azaheterocycles as bir2 and/or bir3 inhibitors. WO2014026882A1, 2014 Reference Source

233. Roche: Azaindolines. WO2014056871A1, 2014. Reference Source

234. Roche: Dimeric compounds. WO2014090709A1, 2014. Reference Source

235. Roche: Indolines. WO2014056755A1, 2014 Reference Source

236. Roche: Tetrahydro-benzodiazepinones. WO2015071393A1, 2015. Reference Source

237. F Seigal BA, Connors WH, Fraley A, et al.: The discovery of macrocyclic XIAP antagonists from a DNA-programmed chemistry library, and their optimization to give lead compounds with in vivo antitumor activity. J Med Chem. 2015; 58(6): 2855-61.

PubMed Abstract | Publisher Full Text | F1000 Recommendation

238. Seneci $P$, Bianchi $A$, Battaglia $C$, et al: Rational design, synthesis and characterization of potent, non-peptidic Smac mimics/XIAP inhibitors as proapoptotic agents for cancer therapy. Bioorg Med Chem. 2009; 17(16): 5834-56. PubMed Abstract | Publisher Full Text

239. Bristol-Myers Squibb: IAP antagonists. WO2014055461A1, 2014 Reference Source

240. Bristol-Myers Squibb: IAP antagonists. WO2015006524A1, 2015 Reference Source

241. Sun H, Nikolovska-Coleska Z, Lu J, et al.: Design, synthesis, and characterization of a potent, nonpeptide, cell-permeable, bivalent Smac mimetic that concurrently targets both the BIR2 and BIR3 domains in XIAP. J Am Chem Soc. 2007; 129(49): 15279-94.

PubMed Abstract | Publisher Full Text | Free Full Text

242. Takeda: Alanine derivatives as inhibitors of apoptosis proteins. WO2011016576A1, 2011 Reference Source

243. Takeda: Heterocyclic compound. JP2012176934A, 2012.

244. Tetralogic: IAP inhibitors. WO2010033531A1, 2010 Reference Source

245. Tetralogic: IAP inhibitors. WO2011068926A1, 2011 Reference Source

246. Aegera Therapeutics: Bir domain binding compounds. WO2007101347A1, 2007 Reference Source

247. Aegera Therapeutics: IAP Bir domain binding compounds. WO2010031171A1, 2010 .

Reference Source

248. Aegera Therapeutics: Functionalized pyrrolidines and use thereof as iap inhibitors. WO2010015090A1, 2010. Reference Source

249. Avila Therapeutics: Ligand-directed covalent modification of protein. WO2011082285A1, 2011 Reference Source

250. Aegera Therapeutics: IAP Bir domain binding compounds. US20120141496A1, Reference Source

251. Astex Therapeutics: Bicyclic heterocycle compounds and their uses in therapy. WO2014060767A1, 2014

Reference Source

252. Astex Therapeutics: Bicyclic heterocycle compounds and their uses in therapy
WO2014060768A1, 2014

Reference Source

253. Astex Therapeutics: Bicyclic heterocycle compounds and their uses in therapy. WO2014060770A1, 2014

Reference Source

254. Rockefeller University: Mitochondrial targeted stimulators of apoptosis. US20130244325A1, 2013.

Reference Source

255. Wong H, Gould SE, Budha N, et al.: Learning and confirming with preclinical studies: modeling and simulation in the discovery of GDC-0917, an inhibitor of apoptosis proteins antagonist. Drug Metab Dispos. 2013; 41(12): 2104-13. PubMed Abstract | Publisher Full Text

256. F Zhang Y, Seigal BA, Terrett NK, et al:: Dimeric Macrocyclic Antagonists of Inhibitor of Apoptosis Proteins for the Treatment of Cancer. ACS Med Chem Lett. 2015; 6(7): 770-5.

PubMed Abstract | Publisher Full Text | Free Full Text | F1000 Recommendation

257. Flygare JA, Fairbrother WJ: Small-molecule pan-IAP antagonists: a paten review. Expert Opin Ther Pat. 2010; 20(2): 251-67.

PubMed Abstract | Publisher Full Text

258. Dubrez L, Berthelet J, Glorian V: IAP proteins as targets for drug development in oncology. Onco Targets Ther. 2013; 9: 1285-304. PubMed Abstract | Publisher Full Text | Free Full Text

259. F Silke J, Vaux DL: IAP gene deletion and conditional knockout models. Semin Cell Dev Biol. 2015; 39: 97-105.

PubMed Abstract | Publisher Full Text | F1000 Recommendation

260. Beug ST, LaCasse EC, Korneluk RG: Smac mimetics combined with innate immune stimuli create the perfect cytokine storm to kill tumor cells. Oncoimmunology. 2014; 3: e28541. PubMed Abstract | Publisher Full Text | Free Full Text

261. Eckhardt I, Weigert A, Fulda S: Identification of IRF1 as critical dual regulator of Smac mimetic-induced apoptosis and inflammatory cytokine response. Cell Death Dis. 2014; 5(12): e1562.

PubMed Abstract | Publisher Full Text | Free Full Text

262. F Janzen DM, Tiourin E, Salehi JA, et al:: An apoptosis-enhancing drug overcomes platinum resistance in a tumour-initiating subpopulation of ovarian cancer. Nat Commun. 2015; 6: 7956

PubMed Abstract | Publisher Full Text | Free Full Text | F1000 Recommendation

263. $\mathrm{F}$ Yang $\mathrm{C}$, Wang $\mathrm{H}$, Zhang $\mathrm{B}$, et al:: LCL161 increases paclitaxel-induced apoptosis by degrading cIAP1 and cIAP2 in NSCLC. J Exp Clin Cancer Res. 2016; 35(1): 158.

PubMed Abstract | Publisher Full Text | Free Full Text | F1000 Recommendation

264. F Matzinger $\mathrm{O}$, Viertl $\mathrm{D}$, Tsoutsou $\mathrm{P}$, et al:: The radiosensitizing activity of the SMAC-mimetic, Debio 1143, is TNF $\alpha$-mediated in head and neck squamous cell carcinoma. Radiother Oncol. 2015; 116(3): 495-503.

PubMed Abstract | Publisher Full Text | F1000 Recommendation

265. TetraLogic Pharmaceuticals: Study of Birinapant in Combination With Conatumumab in Subjects With Relapsed Ovarian Cancer. In ClinicalTrials.Gov. [cited Dec, 2016], 2016.

Reference Source

266. F Amaravadi RK, Schilder RJ, Martin LP, et al.: A Phase I Study of the SMAC Mimetic Birinapant in Adults with Refractory Solid Tumors or Lymphoma. Mol Cancer Ther. 2015; 14(11): 2569-75. PubMed Abstract | Publisher Full Text | F1000 Recommendation

267. Noonan AM, Bunch KP, Chen J, et al:: Pharmacodynamic markers and clinical results from the phase 2 study of the SMAC mimetic birinapant in women with relapsed platinum-resistant or -refractory epithelial ovarian cancer. Cancer. 2016; 122(4): 588-97. PubMed Abstract | Publisher Full Text | Free Full Text

268. Senzer NN, LoRusso P, Martin LP, et al.: Phase II Clinical Activity and Tolerability of the SMAC-Mimetic Birinapant (TL32711) plus Irinotecan in Irinotecan-Relapsed/Refractory Metastatic Colorectal Cancer. In ASCO 2013, ASCO: Chicago, IL, 2013; 31: 3621. Reference Source

269. Grothey A, Van Cutsem E, Sobrero A, et al.: Regorafenib monotherapy for previously treated metastatic colorectal cancer (CORRECT): an international, multicentre, randomised, placebo-controlled, phase 3 trial. Lancet. 2013; 381(9863): 303-12. PubMed Abstract | Publisher Full Text

270. BusinessWire: Medivir Strengthens Its Clinical Pipeline by Entering into Agreement to Acquire a Portfolio of Clinical Stage Oncology Programs. (accessed 12/21/2016). Reference Source

271. Infante JR, Dees EC, Olszanski AJ, et al.: Phase I dose-escalation study of LCL161, an oral inhibitor of apoptosis proteins inhibitor, in patients with advanced solid tumors. J Clin Oncol. 2014. 32(28): 3103-10. PubMed Abstract | Publisher Full Text

272. West AC, Martin BP, Andrews DA, et al:: The SMAC mimetic, LCL-161, reduces survival in aggressive MYC-driven lymphoma while promoting susceptibility to endotoxic shock. Oncogenesis. 2016; 5: e216. PubMed Abstract | Publisher Full Text | Free Full Text

273. Novartis Pharmaceuticals: A Randomized, Phase 2, Neoadjuvant Study of 
Weekly Paclitaxel With or Without LCL161 in Patients With Triple Negative Breast Cancer. In ClinicalTrials.Gov. [cited Dec, 2016], 2016. Reference Source

274. Parton M, Bardia A, Kummel S, et al.: A phase II, open-label, neoadjuvant, randomized study of LCL161 with paclitaxel in patients with triple-negative breast cancer (TNBC). In ASCO 2015, ASCO: Chicago, IL, 2015; 33: 128. Reference Source

275. F Chesi M, Mirza NN, Garbitt VM, et al.: IAP antagonists induce anti-tumor immunity in multiple myeloma. Nat Med. 2016; 22(12): 1411-20. PubMed Abstract | Publisher Full Text | F1000 Recommendation

276. F Beug ST, Beauregard CE, Healy C, et al.: Smac mimetics synergize with immune checkpoint inhibitors to promote tumour immunity against glioblastoma. Nat Commun. 2017; 8: 14278.

PubMed Abstract | Publisher Full Text | Free Full Text | F1000 Recommendation

277. Hurwitz H, Pitot HC, Smith DC, et al.: First-in-human, pharmacokinetic (PK), and pharmacodynamics (PD) phase I study of Debio1143 (AT-406) in patients with advanced cancer: Final results. In ASCO 2014, ASCO: Chicago, IL, 2014; 32 . 2532. Reference Source

278. Thompson N, Ahn M, Chessari G, et al:: Characterization of a Potent XIAP and cIAP1 Dual Antagonist in Models of Melanoma and Leukemia. In 24th EORTC$\mathrm{NCl}-\mathrm{AACR}$ Symposium on Molecular Targets and Cancer Therapeutics, AACR: Dublin, Ireland, 2012.

279. Welsh K, Milutinovic S, Ardecky RJ, et al.: Characterization of Potent SMAC Mimetics that Sensitize Cancer Cells to TNF Family-Induced Apoptosis. PLOS One. 2016; 11(9): e0161952. PubMed Abstract | Publisher Full Text | Free Full Text

280. González-López M, Welsh K, Finlay D, et al:: Design, synthesis and evaluation of monovalent Smac mimetics that bind to the BIR2 domain of the anti-apoptotic protein XIAP. Bioorg Med Chem Lett. 2011; 21(14): 4332-6. PubMed Abstract | Publisher Full Text | Free Full Text

281. Lu J, McEachern D, Sun H, et al.: Therapeutic potential and molecular mechanism of a novel, potent, nonpeptide, Smac mimetic SM-164 in combination with TRAIL for cancer treatment. Mol Cancer Ther. 2011; 10(5): $902-14$.

PubMed Abstract | Publisher Full Text | Free Full Text

282. Metwalli AR, Khanbolooki S, Jinesh G, et al: Smac mimetic reverses resistance to TRAIL and chemotherapy in human urothelial cancer cells. Cancer Biol Ther.
2010; 10(9): 885-92

PubMed Abstract | Publisher Full Text | Free Full Text

283. Lecis D, Drago C, Manzoni L, et al.: Novel SMAC-mimetics synergistically stimulate melanoma cell death in combination with TRAIL and Bortezomib. Br J Cancer. 2010; 102(12): 1707-16.

PubMed Abstract | Publisher Full Text | Free Full Text

284. F Cristofanon S, Abhari BA, Krueger M, et al.: Identification of RIP1 as a critical mediator of Smac mimetic-mediated sensitization of glioblastoma cells for Drozitumab-induced apoptosis. Cell Death Dis. 2015; 6(4): e1724.

PubMed Abstract | Publisher Full Text | Free Full Text | F1000 Recommendation

285. F Tuthill MH, Montinaro A, Zinngrebe J, et al.: TRAIL-R2-specific antibodies and recombinant TRAIL can synergise to kill cancer cells. Oncogene. 2015; 34(16): 2138-44.

PubMed Abstract | Publisher Full Text | Free Full Text | F1000 Recommendation

286. Basit F, Humphreys R, Fulda S: RIP1 protein-dependent assembly of a cytosolic cell death complex is required for inhibitor of apoptosis (IAP) inhibitormediated sensitization to lexatumumab-induced apoptosis. J Biol Chem. 2012; 287(46): 38767-77.

PubMed Abstract | Publisher Full Text | Free Full Text

287. Amm HM, Zhou T, Steg AD, et al.: Mechanisms of drug sensitization to TRA-8, an agonistic death receptor 5 antibody, involve modulation of the intrinsic apoptotic pathway in human breast cancer cells. Mol Cancer Res. 2011; 9(4): 403-17.

PubMed Abstract | Publisher Full Text | Free Full Text

288. Varfolomeev E, Alicke B, Elliott JM, et al: $\mathbf{X}$ chromosome-linked inhibitor of apoptosis regulates cell death induction by proapoptotic receptor agonists. J Biol Chem. 2009; 284(50): 34553-60. PubMed Abstract | Publisher Full Text | Free Full Text

289. F Beug ST, Tang VA, LaCasse EC, et al:: Smac mimetics and innate immune stimuli synergize to promote tumor death. Nat Biotechnol. 2014; 32(2): 182-90. PubMed Abstract | Publisher Full Text | Free Full Text | F1000 Recommendation

290. F Dobson CC, Naing T, Beug ST, et al:: Oncolytic virus synergizes with Smac mimetic compounds to induce rhabdomyosarcoma cell death in a syngeneic murine model. Oncotarget. 2017; 8(2): 3495-508.

PubMed Abstract | Publisher Full Text | Free Full Text | F1000 Recommendation

291. MacKenzie A, LaCasse E: Inhibition of IAP's protection by Diablo/Smac: new therapeutic opportunities? Cell Death Differ. 2000; 7(10): 866-7.

PubMed Abstract | Publisher Full Text 


\section{Open Peer Review}

\section{Current Peer Review Status:}

\section{Editorial Note on the Review Process}

Faculty Reviews are review articles written by the prestigious Members of Faculty Opinions. The articles are commissioned and peer reviewed before publication to ensure that the final, published version is comprehensive and accessible. The reviewers who approved the final version are listed with their names and affiliations.

\section{The reviewers who approved this article are:}

\section{Version 1}

\section{Robert G Korneluk}

Apoptosis Research Centre, Children's Hospital of Eastern Ontario Research Institute, Ottawa, ON, Canada

\section{Eric C LaCasse}

Apoptosis Research Centre, Children's Hospital of Eastern Ontario Research Institute, Ottawa, ON, Canada

Shawn T Beug

Apoptosis Research Centre, Children's Hospital of Eastern Ontario Research Institute, Ottawa, ON, Canada

Competing Interests: No competing interests were disclosed.

\section{Domagoj Vucic}

Department of Early Discovery Biochemistry, Genentech, South San Francisco, South San Francisco, CA, USA Competing Interests: No competing interests were disclosed.

\section{Craig M Walsh}

University of California, Irvine, Irvine, CA, USA

Competing Interests: No competing interests were disclosed. 
The benefits of publishing with F1000Research:

- Your article is published within days, with no editorial bias

- You can publish traditional articles, null/negative results, case reports, data notes and more

- The peer review process is transparent and collaborative

- Your article is indexed in PubMed after passing peer review

- Dedicated customer support at every stage

For pre-submission enquiries, contact research@f1000.com 